\title{
Agroindustrial Byproducts for the Generation of Biobased Products: Alternatives for Sustainable Biorefineries
}

\begin{abstract}
Rafael Rodrigues Philippini*, Sabrina Evelin Martiniano, Avinash P. Ingle, Paulo Ricardo Franco Marcelino, Gilda Mariano Silva, Fernanda Gonçalves Barbosa, Júlio César dos Santos and Silvio Silvério da Silva*
\end{abstract}

Engineering School of Lorena, University of São Paulo, Lorena, São Paulo, Brazil

The integrated approach in biorefinery mainly involves the utilization of various agroindustrial byproducts such as raw materials for the production of several biobased products like biofuels, bioenergy, and other high-value chemicals. Biofuels are the backbone of biorefineries, however, production of value-added biomolecules such as biopigments, biopolymers, biosurfactants, and nutritional yeast has been attracting great attention. The production of these biomolecules using traditional approaches has been extensively studied in the last few years owing to their promising application in different industries such as chemical, food/feed, and pharmaceuticals for the development of novel products for mankind. Moreover, the production of such biomolecules using lignocellulosic, starchy, and some other agroindustrial byproducts is still not fully explored. Hence, there is a huge scope in the development of sustainable biorefining approaches to make the technology cost-effective. The lignocellulosic biomasses usually used in biorefineries are mainly composed of cellulose, hemicellulose, and lignin, whereas starchy materials, besides starch, usually contain, protein, lipids, and some micronutrients. The processing of these biomasses through successive steps like pretreatments, enzymatic hydrolysis, and fermentation is essentially required to obtained final biobased products. Considering certain bottlenecks of above-mentioned conventional biorefineries approaches, new technologies have been proposed for the improved pretreatment of biomass and efficient enzymatic hydrolysis in order to minimize the concentration of toxic inhibitors in resulting hydrolysate. In this review, we highlighted the different agroindustrial byproducts and their applications for the production of valuable biorefinery products.

Keywords: biorefineries, biopigments, biopolymers, biosurfactants, nutritional yeast, pretreatments

\section{INTRODUCTION}

The continuous increase in human population with faster pace and urbanization has tremendously increased the energy requirements over the past few decades. The utilization of fossil fuels as transportation fuel has created several concerns such as depletion in their resources and environmental damage due to emission of greenhouse gases (GHGs), which further leads to climate 
change and global warming. In order to overcome these drawbacks, research efforts have been taken to develop sustainable biorefineries. The concept of biorefinery is not new at all; the sugar industry from the 18th century and the wood pulp and paper industry from the 19th century were the first rough industrial models of biorefineries. Since then, a great number of platforms have been developed based on the use of different raw materials (Carvalheiro et al., 2008).

Biorefineries deal with the utilization of biomass and their conversion to fuels, electricity, heat, high-value chemicals, and other important biobased products through different processes (Ubando et al., 2019; Kumar and Yaashikaa, 2020). These are described as analogous platform to the traditional petroleumbased refineries and are found to play a pivotal role in the production of alternatives to fossil fuels and other biobased products under the umbrella of green energy policies. According to Moncada et al. (2016), the integrated use of biorefinery can be more useful, in this context, with different biomassbased platforms such as syngas, sugars (C5/C6), plant-based oil, algae oil, organic solutions, lignin, and pyrolysis oil, which could be combined according to the needs of the market to obtain integrated biorefineries for maximum exploitation of raw materials and generation of a variety of products.

Moreover, biorefineries can play an important role in the economic development of poor and developing countries, because it helps to generate employment or jobs for needy people. Similarly, the production of commodities and specialties from low-cost feedstock, especially the organic waste, helps to manage the issue of waste generation (developing countries have 50\% higher organic waste than do developed countries) and also to generate revenue (Dhamodharan et al., 2020). It is a true and well-known fact that biorefineries are playing a key role in processing of biomasses or bioresources into a variety of high-value bioproducts mentioned above; on the other hand, we cannot deny the fact that the economic viability of secondgeneration bioenergies is still a major challenge.

The biorefineries usually offer to add value to biomass supply chains through the production of various biobased products. However, the existing complex pathways in biorefineries raise considerable concerns that mainly include the selection and design of best-performance routes. Moreover, it is also influenced by a number of variables like spatial variable (land dispersion and land productivity), logistical variables (energy density, transportation distance, etc.), and technological variables (mass recovery rate, etc.). Apart from these, in biomass supply chains, maintaining the relations between supplier and buyer is not easy because of seasonality, fluctuating harvest rates, or biomass quality. This is the reason that farmers and biomass processing companies are usually hesitant to sign continuous supply contracts (Yazan et al., 2017). As discussed above, cost of feedstocks (biomass should be available at attractive costs), storage and delivery of biomass (the year-round operation of biorefineries requires that biomass feedstock produced seasonally be stored until use, but storage and transportation of biomass feedstock required additional initial investments and operating costs for biorefineries), and absence of price discovery institutions in bioenergy feedstock markets (no such institutions exist to facilitate markets in non-traditional feedstock sources). Owing to the absence of such institutions, multidimensional price discovery processes pose potential barriers to the expanded use of biofuels, feedstock conversion technologies and costs (conversion of a variety of feedstocks into liquid fuels and other valuable products are the other major cost components), and infrastructure investments for biorefineries (requirement of large capital investment for commercial production facilities) are some of the important factors that affect the economic viability of biorefineries (National Research Council, 2011). Nowadays, almost all kinds of biorefineries are facing problems of economic viability, which affects their success owing to all the abovementioned challenges and barriers.

Biomasses from different sectors such as agricultural, forestry, industrial, and municipal wastes and aquatic biomass (algae and seaweed) can be utilized for biorefinery development. In fact, each generated residue can be employed for a specific biorefinery concept, attending to local availability, and allowing their development and production according to different locations, local market trends, and requirements. The utilization of local biomass is also an interesting approach, not requiring longdistance travels for feedstock, thus reducing fuel consumption by different transportation ways (Dhamodharan et al., 2020).

Various traditional biorefinery products such as acrylic and lactic acid, liquid fuels biodiesel and ethanol, and natural sweeteners such as sorbitol and xylitol have been already developed by green chemistry companies (Özüdoğru et al., 2019). Besides, many other bioproducts can be developed in different biorefineries using renewable raw materials (Mood et al., 2013; Kumar and Yaashikaa, 2020), such as biopigments, biopolymers, biosurfactants (BSs), and nutritional yeasts.

This review is mainly focused on the utilization of potential agroindustrial byproducts for the generation of biobased products under the biorefinery scenario. Moreover, major drawbacks and plausible solutions in the employment of pretreatment technologies for biorefineries are also discussed in this review. Considering that most articles are based on traditional bioproduct approaches in biorefineries, this review is focused on different biomolecules that are not already described in the context of integrated biorefineries, namely, biopolymers, nutritional yeasts, biopigments, and BSs. These bioproducts are highlighted to understand how the currently available biorefineries (as ethanol-producing facilities) and their production might be associated with the available facilities and procedures. Moreover, some bioproducts obtained from filamentous fungi or bacteria with interesting properties such as lasiodiplodan, Monascus biopigments, and polyhydroxyalkanoates (PHA) are also briefly discussed.

\section{AGROINDUSTRIAL BYPRODUCTS}

The agroindustrial byproducts are mostly derived from the processing of various crop plants around the world. The different plants generate different kinds of byproducts; for example, non-woody vegetables generate residual and structural fractions that can be utilized for the preparation of various biobased 


\section{BIOPOLYMER FROM BIOMASS}

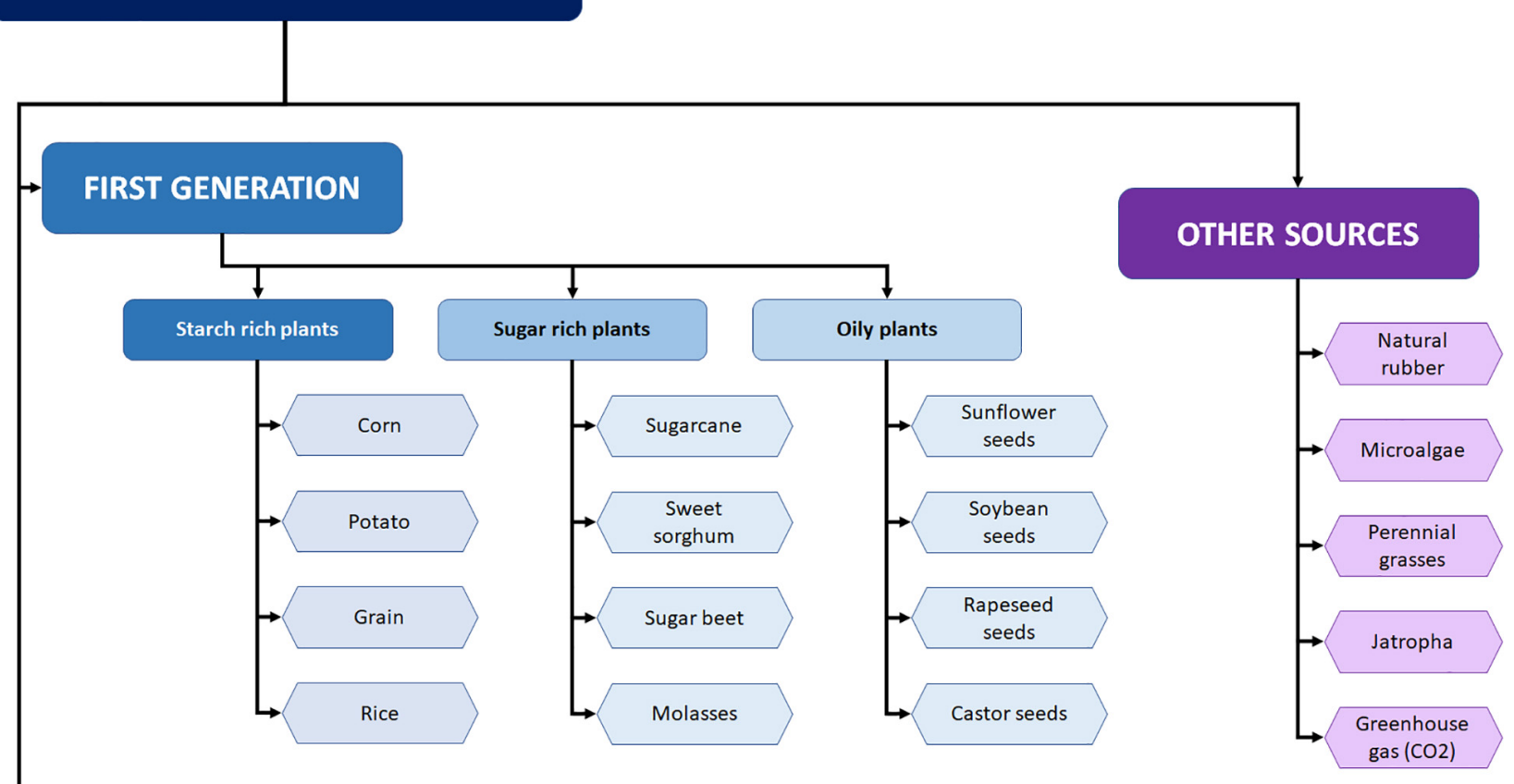

\section{SECOND GENERATION}

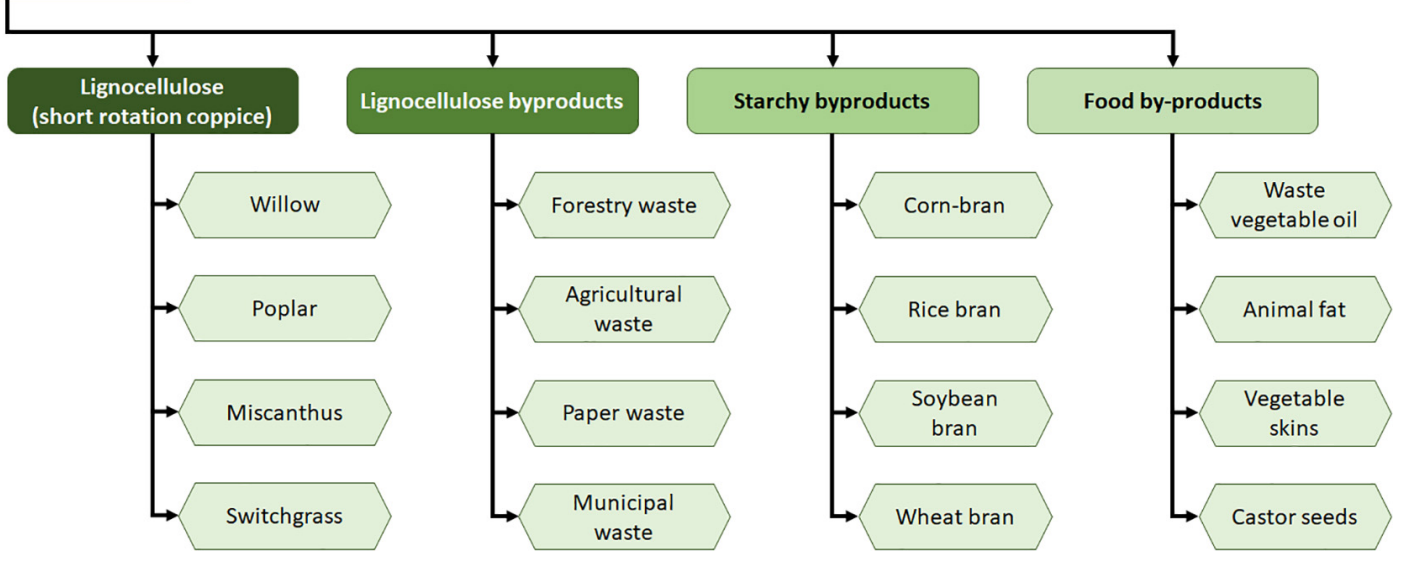

FIGURE 1 | Application of agroindustrial byproducts for the generation of biobased products.

products. Similarly, the agroindustrial byproducts can be used as a raw material in biorefineries for the release of sugars, proteins, oils and other micronutrients, which can be employed for the development of different media compositions (Ascencio et al., 2019; Chaturvedi et al., 2019). Among some successful biorefineries, we can highlight Abengoa, Beta Renewables, DuPont, GranBio, Poet-DSM, and Raizen, which operate on the commercial scale by using lignocellulosic feedstocks and different pretreatment processes.

Moreover, lignocellulosic and starchy byproducts present great potential application in the biorefineries, because they are (1) widely distributed around the globe; (2) rich sources of carbohydrates, proteins, and other relevant nutrients; (3) able to be hydrolyzed using the proper pretreatment techniques; and (4) can be used for generating different biotechnological products according to the market demands (Werpy and Petersen, 2004; Kumar and Yaashikaa, 2020). Figure 1 summarizes some of the agroindustrial byproducts commonly used for the generation of biobased products.

\section{Lignocellulosic Byproduct}

Lignocellulosic biomass is the most abundant renewable carbon source in the world. The traditional lignocellulosic materials can be grouped mainly into three categories: (i) agricultural residues, 
(ii) forestry residues, and (iii) energy crops. Among these, agricultural residues mainly include rice straw, rice husk, barley straw, wheat straw, wheat stover, sorghum straw, corn cobs, corn stover, sugarcane bagasse, and sugarcane straw. Forestry residues comprise woods, woodchips, wood branches, wood sawdust, fruit bunch, and so forth; the last one is energy crops, which mainly includes switchgrass, miscanthus, energy cane, and grass (Dhamodharan et al., 2020).

These materials vary in composition depending on their regions; however, the basic constituents include cellulose, hemicellulose, and lignin. Among these, cellulose is the linear biopolymer and is present in higher amounts (23-53\%) in lignocellulosic biomass, followed by hemicellulose (20-35\%), which is considered as a heteropolysaccharide majorly composed of xylose. The other macromolecular fraction, lignin (10-25\%), is a complex biomolecule of polyphenols that acts as a physical barrier to microorganisms and enzymes (Ascencio et al., 2019).

Glucose can be easily assimilated by different microorganisms, and it is the most promising carbohydrate fraction used in biorefineries around the world. Xylose is another important sugar owing to its high prevalence in vegetal biomass, and it is widely used for the development of biomolecules such as ethanol and xylitol (Unrean and Ketsub, 2018). However, in order to obtain glucose and xylose from carbohydrate fractions of lignocellulosic byproducts, the polymers have to be hydrolyzed using specific industrial approaches. The methods currently employed for this purpose include the enzymatic hydrolysis of cellulose into glucose using cellulase-rich enzymatic preparations. However, before enzymatic hydrolysis, a pretreatment step is required to decrease biomass recalcitrance (Chandel et al., 2013, 2018). The pretreatment step is one of the most important bottlenecks for the viability of biorefineries.

\section{Starchy Byproduct}

The starchy biomass is directly linked to human development, as major civilizations became prosperous owing to the agriculture implementation and grain cultivation. They are nowadays one of the most economically relevant global products, as they are utilized for both food and feed and employed in the development of beverages and pharmaceutical products alike.

Generally, considering research works dealing with biorefineries, starchy byproducts are still underused materials when compared with lignocellulosic feedstock for the generation of bioproducts, even though they are great sources of carbohydrate and nitrogen, which can be easily recovered by traditional pretreatments. Taking this point into account, it is possible to aggregate these biomasses to biorefineries, increasing its versatility, reducing production costs, and allowing the generation of several other bioproducts.

The starchy biomass is majorly composed of starch, which is generally present in seeds and tubers, and its constituents are amylose and amylopectin (Chaturvedi et al., 2019). Grains like barley, corn, rice, soybean, and wheat are composed of three fractions: endosperm (presenting the starchy portion, responsible for seed maintenance during the dormant phase and before germination), germ (presenting the vitamins, proteins, minerals, and oils, responsible for the development of the plant), and bran (the external layer that covers the grain, protecting the endosperm and germ against external agents) (Barrett et al., 2020). The processing of grains for oil extraction removes bran from seeds, which is traditionally used as feed. Bran is a rich source of lipids, minerals, proteins, and residual starch. Besides grains, cassava, a root tuber, is another important starchy biomass. All these starchy materials have been cultivated all over the world and used as important feedstock in biotechnological processes, such as for the production of ethanol (Bayitse et al., 2015) and various other bioproducts (Martiniano et al., 2014, 2016; Arruda et al., 2017; Lee et al., 2017).

\section{BIOMASS PRETREATMENT}

Different pretreatment methods have been studied that aimed for the carbohydrate recovery from different agroindustrial residues. The pretreatment methods can be divided into chemical, physical, physico-chemical, and biological processes, which can be applied alone or in combination with different feedstocks, in order to obtain the desired molecules from the different fractions of the biomass (Mood et al., 2013). Several methodologies and/or combinations for different lignocellulosic and starchy biomasses are presented in Table $\mathbf{1}$ along with their advantages and disadvantages. For starchy raw materials, pretreatment can be a general term referring to the techniques used for starch hydrolysis to produce glucose and dextrin (Lee et al., 2017). For lignocellulosic biomass, pretreatment is more commonly used with a more specific meaning, corresponding to the step that is before enzymatic hydrolysis of cellulose and has the main purpose of increasing the enzymatic digestibility of this carbohydrate fraction.

Hydrothermal pretreatments like autohydrolysis and steam explosion are commonly reported in the literature. These methods do not require a chemical catalyst and act mainly on the hemicellulosic fraction of the lignocellulosic materials. These approaches are found to be environmentally and economically appealing for biorefineries, although longer periods and temperature might be necessary for their proper employment (Ruiz et al., 2019).

The most common chemical pretreatments are acid and alkaline. The acid pretreatments vary from the utilization of concentrated and diluted acids, whereas $\mathrm{H}_{2} \mathrm{SO}_{4}$ is the traditionally employed acid for reactions, although $\mathrm{HCl}, \mathrm{HNO}_{3}$, and $\mathrm{H}_{3} \mathrm{PO}_{4}$ can be also utilized (Mood et al., 2013; Solarte-Toro et al., 2019). The utilization of dilute acids results in hydrolysis of the hemicellulose, and it is preferred (compared with concentrated acids) because it is less corrosive to the equipment and generates a lower amount of inhibitory compounds in the obtained hydrolysates (Carvalheiro et al., 2008). Alkaline pretreatments utilize $\mathrm{Ca}(\mathrm{OH})_{2}, \mathrm{NaOH}, \mathrm{KOH}$, and ammonia for lignin removal as well as for the degree of crystallinity of cellulose (Mood et al., 2013). The employment of low pressures and temperatures is presented as an advantage, although in the utilization of some alkalis, alkalis can be converted into irrecoverable salts, which can be incorporated into the employed feedstock (Carvalheiro et al., 2008). 
TABLE 1 | Most relevant pretreatments on different lignocellulosic and starchy biomass.

\begin{tabular}{|c|c|c|c|c|c|}
\hline Biomass type & Pretreatment & Evaluated biomass & Advantages & Disadvantages & References \\
\hline \multirow[t]{12}{*}{$\begin{array}{l}\text { Lignocellulosic } \\
\text { biomasses }\end{array}$} & $\begin{array}{l}\text { Dilute acid }\left(\mathrm{HCl}, \mathrm{HNO}_{3}\right. \\
\left.\mathrm{H}_{3} \mathrm{PO}_{4}\right)\end{array}$ & $\begin{array}{l}\text { Sugarcane bagasse; } \\
\text { sweet sorghum }\end{array}$ & $\begin{array}{l}\text { Compared with the use } \\
\text { of concentrated acids, } \\
\text { results in less corrosion } \\
\text { to the equipment and } \\
\text { lower concentration of } \\
\text { inhibitory compounds; } \\
\text { hydrolysis of } \\
\text { hemicellulose }\end{array}$ & $\begin{array}{l}\text { Requires high } \\
\text { temperature and } \\
\text { pressure }\end{array}$ & $\begin{array}{l}\text { Mood et al., 2013; } \\
\text { Ascencio et al., 2019; } \\
\text { Camargo et al., 2019; } \\
\text { Solarte-Toro et al., } \\
2019\end{array}$ \\
\hline & $\begin{array}{l}\text { Alkaline }\left[\mathrm{Ca}(\mathrm{OH}]_{2}\right. \\
\mathrm{NaOH} ; \mathrm{KOH}\end{array}$ & $\begin{array}{l}\text { Sugarcane } \\
\text { bagasse/straw }\end{array}$ & $\begin{array}{l}\text { Low pressures and } \\
\text { temperatures }\end{array}$ & $\begin{array}{l}\text { Requires high quantity } \\
\text { of reagent; } \\
\text { irrecoverable salts on } \\
\text { feedstock }\end{array}$ & $\begin{array}{l}\text { Carvalheiro et al., 2008; } \\
\text { Mood et al., 2013; } \\
\text { Ascencio et al., } 2019\end{array}$ \\
\hline & Ionic liquids & $\begin{array}{l}\text { Triticale; sugarcane } \\
\text { bagasse/straw; rye } \\
\text { straw }\end{array}$ & $\begin{array}{l}\text { Non-corrosive; can } \\
\text { solubilize all fractions of } \\
\text { biomass }\end{array}$ & $\begin{array}{l}\text { High cost of ionic } \\
\text { liquids }\end{array}$ & $\begin{array}{l}\text { Fu and Mazza, 2011; } \\
\text { Mood et al., 2013; } \\
\text { Usmani et al., } 2020\end{array}$ \\
\hline & Organosolv & Wheat straw; bamboo & $\begin{array}{l}\text { High removal of lignin; } \\
\text { solvents can be reused }\end{array}$ & $\begin{array}{l}\text { High-energy } \\
\text { consumption; high } \\
\text { viscosity of some } \\
\text { solvents }\end{array}$ & $\begin{array}{l}\text { Wang et al., 2017; } \\
\text { Mugwagwa and } \\
\text { Chimphango, } 2020\end{array}$ \\
\hline & Mechanical extrusion & $\begin{array}{l}\text { Soybean hull; } \\
\text { sugarcane bagasse }\end{array}$ & $\begin{array}{l}\text { Cellulose matrix } \\
\text { disruption; used to a } \\
\text { variety of biomass }\end{array}$ & $\begin{array}{l}\text { Costly and } \\
\text { energy-intensive }\end{array}$ & $\begin{array}{l}\text { Lamsal et al., 2010; } \\
\text { Zheng and Rehmann, } \\
\text { 2014; Kumar and } \\
\text { Sharma, } 2017\end{array}$ \\
\hline & Milling & $\begin{array}{l}\text { Sugarcane } \\
\text { bagasse/straw; grasses } \\
\text { corn bran }\end{array}$ & $\begin{array}{l}\text { Size reduction } \\
\text { enhances digestibility of } \\
\text { biomass }\end{array}$ & $\begin{array}{l}\text { Costly and } \\
\text { energy-intensive }\end{array}$ & $\begin{array}{l}\text { Kumar et al., 2009; } \\
\text { Alvira et al., 2010; } \\
\text { Philippini et al., 2018; } \\
\text { Seta et al., } 2020\end{array}$ \\
\hline & Liquid hot water & $\begin{array}{l}\text { Rice bran sugarcane } \\
\text { bagasse }\end{array}$ & $\begin{array}{l}\text { Environmentally and } \\
\text { economically } \\
\text { appealing; improved } \\
\text { accessibility to } \\
\text { cellulolytic enzymes }\end{array}$ & $\begin{array}{l}\text { Large heat } \\
\text { consumption; heat } \\
\text { recovery; expensive } \\
\text { energy downstream }\end{array}$ & $\begin{array}{l}\text { Ruiz et al., 2019; } \\
\text { Martiniano et al., } 2014\end{array}$ \\
\hline & Steam explosion & $\begin{array}{l}\text { Corn stover; sugarcane } \\
\text { bagasse }\end{array}$ & $\begin{array}{l}\text { Short residence time } \\
\text { and low energy } \\
\text { consumption; requires } \\
\text { no chemical catalyst }\end{array}$ & $\begin{array}{l}\text { Risk of lignin } \\
\text { condensation and } \\
\text { precipitation; } \\
\text { generation of } \\
\text { fermentation inhibitors }\end{array}$ & $\begin{array}{l}\text { Alvira et al., 2010; Ruiz } \\
\text { et al., } 2019\end{array}$ \\
\hline & Microwave & $\begin{array}{l}\text { Sugarcane bagasse; } \\
\text { switch grass }\end{array}$ & $\begin{array}{l}\text { Easy operation; less } \\
\text { energy requirement; } \\
\text { high heating capacity }\end{array}$ & $\begin{array}{l}\text { Distribution of power; } \\
\text { low radiation } \\
\text { penetration; difficult to } \\
\text { scale up }\end{array}$ & $\begin{array}{l}\text { Campañone et al., } \\
\text { 2012; Sun et al., 2016; } \\
\text { Zhu et al., 2016; Kumar } \\
\text { and Sharma, } 2017\end{array}$ \\
\hline & Ultrasonication & $\begin{array}{l}\text { Corn stover; sugarcane } \\
\text { bagasse }\end{array}$ & High efficiency & Difficult to scale up & $\begin{array}{l}\text { Zhang et al., 2008; } \\
\text { Yachmenev et al., } \\
\text { 2009; Bussemaker and } \\
\text { Zhang, } 2013\end{array}$ \\
\hline & $\begin{array}{l}\text { Hydrodynamic } \\
\text { cavitation }\end{array}$ & $\begin{array}{l}\text { Corn stover; reed; } \\
\text { sugarcane bagasse }\end{array}$ & $\begin{array}{l}\text { High lignin removal; } \\
\text { high glucose recovery }\end{array}$ & $\begin{array}{l}\text { Use of low solids } \\
\text { quantity in the reactor; } \\
\text { new technology: } \\
\text { requires more study }\end{array}$ & $\begin{array}{l}\text { Kim et al., 2015; } \\
\text { Nakashima et al., 2016; } \\
\text { Terán-Hilares et al., } \\
2020\end{array}$ \\
\hline & $\begin{array}{l}\text { Hemicellulolytic and } \\
\text { cellulolytic enzymes }\end{array}$ & $\begin{array}{l}\text { Sugarcane bagasse; } \\
\text { wheat bran }\end{array}$ & $\begin{array}{l}\text { Ecofriendly option; } \\
\text { application of } \\
\text { combined enzymes }\end{array}$ & $\begin{array}{l}\text { High cost; high time of } \\
\text { pretreatment; } \\
\text { purification requirement }\end{array}$ & $\begin{array}{l}\text { Akhtar et al., 2016; } \\
\text { Paye et al., 2016; } \\
\text { Aktas-Akyildiz et al., } \\
2020\end{array}$ \\
\hline \multirow[t]{2}{*}{ Starch biomasses } & $\begin{array}{l}\text { Dilute acid }(\mathrm{HCl} \\
\left.\mathrm{H}_{2} \mathrm{SO}_{4}\right)\end{array}$ & $\begin{array}{l}\text { Corn bran; potato tuber } \\
\text { mash; potato peel }\end{array}$ & $\begin{array}{l}\text { Rapid technique; low } \\
\text { cost }\end{array}$ & $\begin{array}{l}\text { High formation of } \\
\text { furans that inhibit the } \\
\text { microbial growth in } \\
\text { fermentation process }\end{array}$ & $\begin{array}{l}\text { Tasić et al., 2009; } \\
\text { Khawla et al., 2014; } \\
\text { Philippini et al., 2018 }\end{array}$ \\
\hline & $\begin{array}{l}\text { Enzymatic pretreatment } \\
\text { with amylolytic } \\
\text { enzymes }\end{array}$ & $\begin{array}{l}\text { Cassava; corn starch; } \\
\text { potato peel waste }\end{array}$ & $\begin{array}{l}\text { Rapid technique; low } \\
\text { formation of furans that } \\
\text { inhibit the microbial } \\
\text { growth in fermentation } \\
\text { process }\end{array}$ & Expensive technique & $\begin{array}{l}\text { Regy and Padmaja, } \\
\text { 2013; Bayitse et al., } \\
\text { 2015; Zhu et al., 2016; } \\
\text { Ben Atitallah et al., } \\
2019\end{array}$ \\
\hline
\end{tabular}


TABLE 1 | Continued

\begin{tabular}{|c|c|c|c|c|c|}
\hline Biomass type & Pretreatment & Evaluated biomass & Advantages & Disadvantages & References \\
\hline \multirow{2}{*}{ Glycerol } & $\begin{array}{l}\text { Acidification and ion } \\
\text { exchange process }\end{array}$ & & High efficiency & Expensive technique & $\begin{array}{l}\text { Abdul Raman et al., } \\
2019\end{array}$ \\
\hline & $\begin{array}{l}\text { Microfiltration, } \\
\text { saponification, } \\
\text { acidification, phase } \\
\text { separation, and } \\
\text { biphasic extraction }\end{array}$ & & & & Pitt et al., 2019 \\
\hline Molasses & $\begin{array}{l}\text { Washing and cutting, } \\
\text { diffusion, evaporation, } \\
\text { and crystallization }\end{array}$ & $\begin{array}{l}\text { Beet molasses; } \\
\text { sugarcane molasses }\end{array}$ & $\begin{array}{l}\text { Rapid technique; high } \\
\text { efficiency; low cost }\end{array}$ & High & $\begin{array}{l}\text { Veana et al., 2014; } \\
\text { Roukas and } \\
\text { Kotzekidou, } 2020\end{array}$ \\
\hline
\end{tabular}

Moreover, organosolv and ionic liquids are some of the other pretreatment methods applied for lignocellulosic biomass, presenting as main advantages a high lignin removal and the ability to reuse solvents, but these methods are expensive and require high-energy consumption (Carvalheiro et al., 2008; Mood et al., 2013). Still, recent advances in non-conventional pretreatments have been reported and include methods such as gamma ray, electron beam irradiation, pulsed electric field, and hydrodynamic cavitation, which have been pointed as alternatives to ultrasound in large-scale use (Hassan et al., 2018; Teran-Hilares et al., 2020).

\section{POTENTIAL BIOPRODUCTS FOR BIOREFINERIES}

\section{Biopolymers}

Biopolymers are produced by animals, plants, and microorganisms. The most common are composed of carbohydrates, such as cellulose. Microorganisms such as algae, bacteria, filamentous fungi, and yeasts are capable of producing different biopolymers, which may vary according to anomeric configurations, branching points, and molecule backbone (Vasconcelos et al., 2013; Kagimura et al., 2015). The macromolecular nature of lignocellulosic byproducts may be explored for the development of biorefineries. The biomass fractions like cellulose, hemicellulose, and lignin can be chemically modified for the generation of several bioproducts. As a result, cellulose acetate, carboxymethylcellulose, methylcellulose, and furfural and phenol resins can be obtained (Resende and da Costa, 2019). The ethanol produced in both first- and second-generation platforms can be dehydrated and polymerized for the production of green plastic as an alternative to petroleum-based products (Confente et al., 2019). Moreover, residual starch present in seed materials like bran-like residues (corn, rice, soybean, and wheat) can be readily hydrolyzed for sugar and protein, which can further utilized in fermentation processes (Martiniano et al., 2014; Philippini et al., 2018).
Figure 2 depicts some biomass from the first- and secondgeneration platforms for the development of biopolymers in biorefinery platforms.

There is a widespread utilization of biopolymers, which permits its application in several sectors, such as food/feed, pharmaceutical, and chemical industries, for the development of different high-value products used for cosmetics, buildings, pavement, packing films, and medical, dental, and drug delivery systems (Cunha et al., 2012; Vasconcelos et al., 2013; Kagimura et al., 2015). The biopolymers may also be modified for specific applications. Processes such as acetylation, carboxymethylation, phosphorylation, and sulfonation can be effectively used to enhance the properties and bioactivities of biopolymers such as antioxidant, anti-inflammatory, antiproliferative, and antiviral properties as well as anticoagulant and antithrombotic activities (Vasconcelos et al., 2013; Ye et al., 2013; Kagimura et al., 2015). Recently, biomedical applications of biopolymers like mushroom Lentinus edodes glucan (lentinan) have been studied, and the results obtained revealed that these polymers can act as a cytoprotective agent against the coronavirus disease (COVID19), presenting reduced cytokine-induced NF- $\mathrm{B}$ activation in human alveolar epithelial A549 cells (Murphy et al., 2020).

The biopolymers present a distinguished versatility when compared with other biotechnological products, and they are some of the most promising biomolecules in the perspective of industrial economic viability. According to Industry ARC reports (Industry ARC, 2018), the biopolymer market reached more than USD 650 billion in 2018. The biopolymer packing market alone was valued at USD 4.78 billion in 2019, expecting to reach 22.38 billion by 2035. Major industrial players are Toray Industries, Inc., BASF, Braskem, Arkema, and Spectra Packaging Solutions, according to Mordor Intelligence (2019). The $\beta$-glucan market report from Grand View Research (2017) evaluates more than USD 700 million worth of biopolymer packing will be in demand by 2025, which is prompted by the cosmetic and beverage industries, as well as the paradigm shift from customers in searching for more sustainable and healthier products and their nutraceutical and health benefits. 


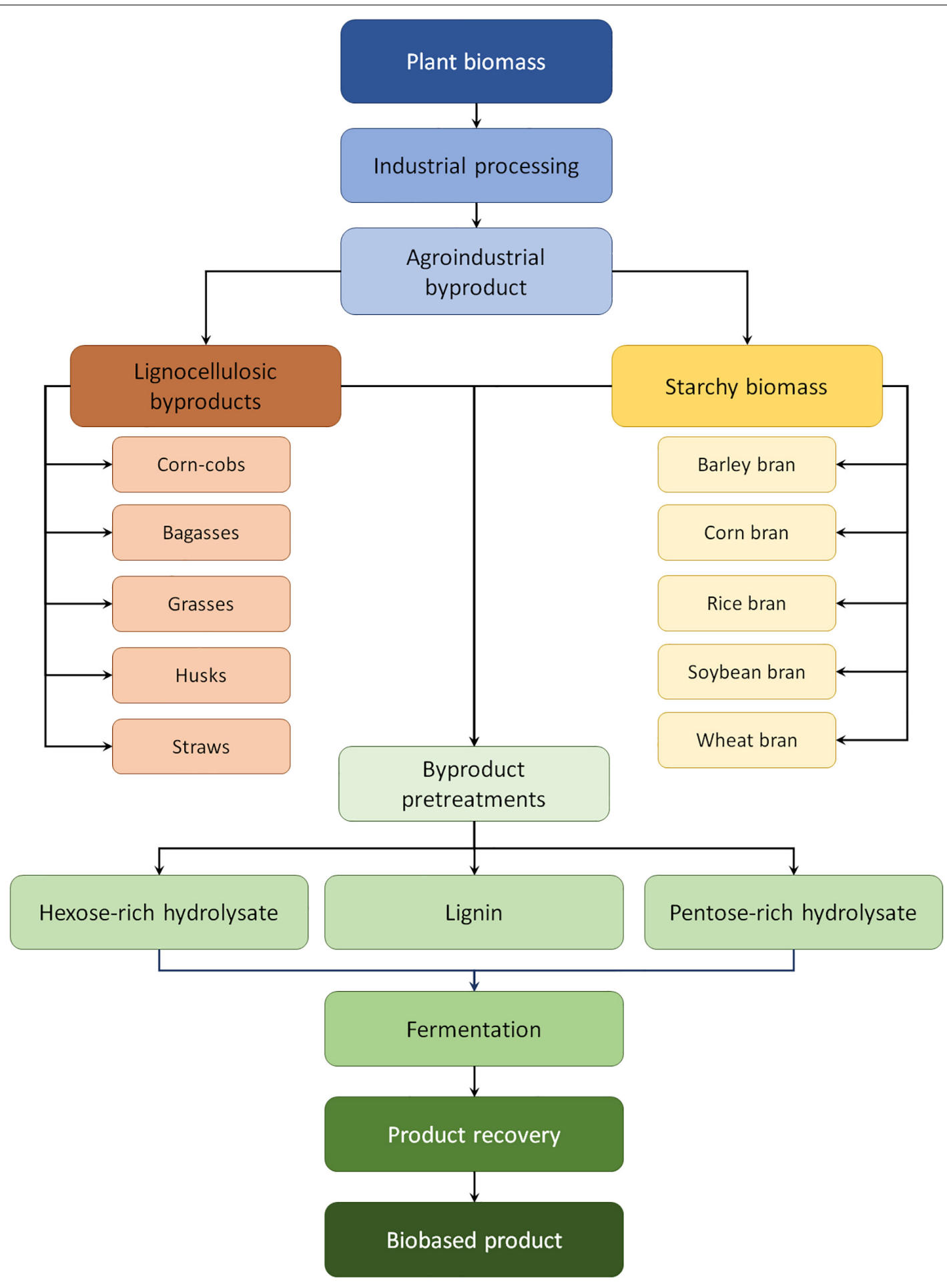

FIGURE 2 | Some feedstocks for the production of biopolymers.

The microbial biopolymers at the industrial level are produced majorly by bacteria and fungi and can be obtained in different forms, such as (i) inside the cell, acting as a carbohydrate storage; (ii) on to the cell wall, acting as a structural and protective layer; and (iii) as an exopolysaccharide, in capsule, slime, or biofilm
(Mahapatra and Banerjee, 2013). Several factors can influence the production of biopolymer in a biorefinery; besides the chosen microorganism, physical parameters such as $\mathrm{pH}$, temperature, aeration, and fermentation time must be controlled in order to achieve good production yields. The medium composition, 
especially carbon and nitrogen sources, as well as micronutrients, additives, and vitamins, must be judiciously selected to reach maximum productivity (Mahapatra and Banerjee, 2013). Most of the production of the industrial biopolymers is elaborated by utilizing glucose or other simple carbohydrates for fermentation.

The agroindustrial biomass is mainly used in the production of bacterial biopolymers like dextran, curdlan, gellan, and xanthan (BeMiller, 2019). However, there are few reports about the use of agroindustrial biomass as growth media for the production of biopolymers from fungi, permitting great exploration potential for the development of new biorefinery platforms in the future (Philippini et al., 2019). The production of $\alpha$-glucans using hemicellulosic hydrolysate obtained after acid hydrolysis of lignocellulosic materials is proposed in some studies. In this context, pullulan (biopolymer) has been produced from Aureobasidium pullulans using hemicellulosic hydrolysates in different concentrations, that is, 17.63 (Chen et al., 2014), 15.77 (Terán-Hilares et al., 2017), and 25.19 g/L (Terán-Hilares et al., 2019), demonstrating the potential of production for this biopolymer in a biorefinery scenario.

The lasiodiplodan is a promising $\beta$-glucan produced by Lasiodiplodia theobromae, which has been studied owing to its pharmaceutical and medical properties (Kagimura et al., 2015). The utilization of soybean molasses for the production of lasiodiplodan from $L$. theobromae MMPI was reported by Acosta et al. (2020). A production of up to $1.06 \mathrm{~g} / \mathrm{L}$ of biopolymer in fermentations containing $10 \mathrm{~g} / \mathrm{L}$ of fermented sugars in the absence/presence of surplus nutritional supplementation has been recorded. In another study, the production of this biopolymer from $L$. theobromae CCT 3966 strain using corn bran acid hydrolysate was reported by Philippini et al. (2018), who obtained $7.47 \mathrm{~g} / \mathrm{L}$ of lasiodiplodan from a medium containing $40 \mathrm{~g} / \mathrm{L}$ of sugars. All these studies proved the potential of agroindustrial byproducts as substitutes of synthetic media for the production of biopolymers like $\beta$-glucans, as they provided both carbon and nitrogen source, allowing the production of such polyvalent biochemical, for application in several industrial sectors.

Chitin is a biopolymer that occurs naturally in fungal cell walls and exoskeleton of arthropods. The production of chitin by yeast Komagataella pastoris was reported by Araújo et al. (2017). In this work, glucose/xylose mixtures were elaborated, suggesting the utilization of xylose-rich lignocellulosic wastes for the production of this biopolymer in biorefineries for cosmetics, food, and pharmaceutical products. Chitosan is a modified biopolymer that can be obtained from chitin by the alkali process. The production of chitosan by Mucorales fungi was evaluated in a study by Berger et al. (2018), in which the biopolymer was produced using cornsteep liquor and papaya peel juice mixtures, achieving maximum concentration of $37.25 \mathrm{mg} / \mathrm{g}$.

The bacterial biopolymers such as PHA polymers can be produced using different bacteria. The environment-friendly nature of these biopolymers suggests the substitution of conventional petroleum plastics for the elaboration of several products such as bottles, drug delivery carriers, films, and medical devices (Li and Wilkins, 2020). The PHA polymer can be produced by utilizing the agroindustrial feedstock as low-cost fermentation media. Among the various agroindustrial byproducts, sugarcane bagasse, rice straw, orange peel, and cassava wastewater have been the most preferably used ( $\mathrm{Yu}$ and Stahl, 2008; Sindhu et al., 2013; Chaleomrum et al., 2014; Sukan et al., 2014).

Several bacterial strains, for example, Bacillus subtilis, Cupriavidus necator, Haloferax mediterranei, Haloferax halophila, Pseudomonas aeruginosa, and Pseudomonas putida have the ability to produce different types of PHA from a variety of feedstocks (Dietrich et al., 2018; Li and Wilkins, 2020). Even though some reports presented that the utilization of lignocellulosic feedstocks is challenging owing to its low fermentability, the utilization of agroindustrial wastes can be an attractive option to produce PHA using xylose-rich hydrolysates (Dietrich et al., 2018). However, inhibitors (furfural, hydroxymethylfurfural, and lignin derivatives) present in the lignocellulosic hydrolysates might affect the capability of fermenting microorganisms and might reduce the productivity (Li and Wilkins, 2020). Considering the potential market of biopolymers, there is an urgent need to overcome these problems so that it can contribute to a sustainable bioeconomy. Moreover, a decrease in dependence on the use of petroleum-based polymers will help to protect the environment. It was confirmed that different biopolymers can be employed in different biorefinery models, such as for hemicellulose valorization (Chen et al., 2014; Terán-Hilares et al., 2019).

To date, a variety of fermenting strains are reported in the literature, however, a proper selection of strains is extremely important, and it can be performed depending on the availability of feedstock to be employed in a biorefinery model. As a consequence, it will be possible to obtain low-cost hydrolysates with appropriate concentration of carbohydrates and nitrogen source without inhibitory compounds from lignocellulosic and starchy materials through enzymatic hydrolysis (Khawla et al., 2014; Bayitse et al., 2015; Aktas-Akyildiz et al., 2020).

It is also important to comment that each application requires different purification standards, so this criterion must be respected. The utilization of agroindustrial residues for the production of the biopolymers must be adequate to each industrial scenario, as residual proteins and other promising biomolecules might be recovered alongside the biopolymer, which might be or might not be interfering in final product destination.

\section{Nutritional Yeast}

Yeasts are generally used in animal feed as nutritional supplements. These microorganisms can be grown directly for nutrition purposes or as a byproduct of fermentative processes, such as in ethanol production, which allows their integrated production in biorefineries. The yeast biomass recovered from bioethanol factories is usually used in several countries as a protein source for cattle (Grand View Research, 2018).

For health and nutritional use, such strains must be generally recognized as safe (GRAS) under the conditions of their specific purposes (FDA, 2019). Therefore, yeast strains used in animal nutrition and the derivate products can be divided into (i) probiotic (live microorganisms) and (ii) prebiotic (dead or 
inactivated yeasts, cell wall fragments, cytoplasmic content of autolyzed yeasts, and also mineral-enriched yeasts) (Graham et al., 2009). These types of yeasts are briefly discussed below.

\section{Single-Cell Protein}

Single-cell protein (SCP) includes dried cells of yeast, fungi, algae, and bacteria, which are used as a protein supplement for both human food and animal feed and can act as an alternative to conventional protein sources. Each group of microorganisms has specific characteristics, but yeasts have attracted a considerable attention owing to their certain advantages, for example, their long history of use in traditional fermentations processes by humanity (Nasseri et al., 2011). Inactivated yeasts are a valuable source of vitamins and minerals, presenting high protein content, which is about $37-42 \%$ of cell dry weight (Andrietta et al., 2017).

The expensive costs of cereals and other supplements, in addition to the high protein requirements in animal feed, increase the interest in alternative and inexpensive new protein sources (Roepcke et al., 2011). The global market of SCP extracts was estimated to be about USD 5.3 billion in 2017 with a compound annual growth rate (CAGR) of $8.6 \%$ during the forecast period 2018-2023 (P\&S Intelligence, 2018). If divided into regions, North America represented the major market share in 2016, followed by Europe, Asia, Latin America, and the Middle East and Africa (Grand View Research, 2018). Microbial protein production is considered a promising method because microorganisms have fast growth and can use locally agroindustrial byproducts as substrate (Juszczyk et al., 2019). However, the conversion of these feedstock into substrates for fermentative processes requires a previous biomass pretreatment, necessary to release sugars, proteins, and other compounds required for yeast growth. Table 2 summarizes some agroindustrial byproducts and yeasts applied for SCP production.

Sugarcane bagasse is a waste of great importance in biorefineries approaches, because their hemicellulosic and cellulosic hydrolysates, obtained after a pretreatment, are rich in pentose and hexoses sugars, respectively, which can be fermented by specific microorganisms. In a study of Candida tropicalis, Magalhães et al. (2018) evaluated the use of sugarcane bagasse hemicellulosic hydrolysate and obtained $16.97 \mathrm{~g} / \mathrm{L}$ of yeast biomass containing $60.05 \%$ protein. Similarly, bran (a starchy byproduct generated during grains processing) can be also applied for SCP production. Xu et al. (2019) compared the use of wheat gluten and soybean protein enzymatic hydrolysates for the growth of Saccharomyces pastorianus, achieving cell growth of 9.23 and $9.85 \mathrm{~g} / \mathrm{L}$, respectively. Gaboardi et al. (2018) studied the use of parboiled rice effluent from maceration tanks for the growth of probiotic Saccharomyces boulardii, producing $3.8 \mathrm{~g} / \mathrm{L}$ of biomass.

Likewise, the production of SCP by solid-state fermentation might be an alternative, conciliating cell growth with a protein enrichment of some agroindustrial byproducts that are currently used in animal feed, such as bran and sugarcane bagasse. Wheat bran was used by Yunus et al. (2015) for the production of Candida utilis and Rhizopus oligosporus biomass under solidstate fermentation, obtaining a biomass (fermented wheat bran) with high crude protein (41\%, dry weight) and high amino acid content. In another study, Samadi et al. (2016) used alkalipretreated sugarcane bagasse as a substrate for the growth of Saccharomyces cerevisiae by solid-state fermentation in a tray reactor, enhancing the protein content of sugarcane bagasse by up to $13.41 \%$.

Wastewater from the pulping process is another residue that can be used for the production of SCP by yeasts. Hu et al. (2015) evaluated the use of black liquor (a lignin fraction obtained from alkali pretreatment of lignocellulosic biomass after the pulping process) for the production of SCP of C. utilis, obtaining $12.6 \mathrm{~g} / \mathrm{L}$ of biomass and $39.82 \%$ total amino acid content. Furthermore, bamboo wastewater from bamboo pulping and papermaking was used for SCP production by C. utilis, achieving $19.17 \mathrm{~g} / \mathrm{L}$ of yeast biomass (Li et al., 2009). Wastewater might be considered as a good carbon and nitrogen source for yeast growth (Hu et al., 2015), in addition to providing an alternative treatment for this type of industrial residue.

Urban wastes constitute other alternative substrates for the production of SCP. Benabda et al. (2018) produced cell biomass using a commercial baker's yeast from enzymatic bread waste hydrolysate, with a yield of $0.77 \mathrm{~g} / \mathrm{g}$. In another study, Choi and Park (2003) produced cell biomass of four yeast species using waste cabbage juice treated with different pretreatments, achieving a protein content above $30 \%$ and major cell growth of about $11 \mathrm{~g} / \mathrm{L}$. Moreover, other agroindustrial byproducts, such as residual oils, can also be used for SCP. Juszczyk et al. (2019) studied the production of Yarrowia lipolytica biomass by using raw glycerol from rapeseed oil, obtaining cell biomass composed of up to $46.1 \%$ of protein and $21.3 \mathrm{~g} / \mathrm{L}$ of biomass. Zheng et al. (2005) evaluated the growth of five yeast species in salad oil manufactured wastewater, with maximum protein production of $26 \%$ (dry weight) by C. utilis. The use of wastewaters and urban wastes might be an alternative to conciliate the production of SCP and waste treatment and valorization.

\section{Mineral-Enriched Yeasts}

Mineral enrichment of yeast biomass is a new concept; moreover, the interest in the use of agroindustrial byproducts as feedstock is increasing along with recent advances in biorefineries. Yeasts are capable of incorporating high concentrations of minerals into biomolecules and, therefore, can be applied as carriers for minerals and other compounds essential for health (Roepcke et al., 2011; Kieliszek et al., 2017). In general, minerals consumed from enriched yeasts are more bioavailable and have a low risk of toxicity (Demirci and Pometto, 2000; Roepcke et al., 2011); besides, their consumption is associated with the benefits of consuming yeast biomass, a source naturally rich in proteins and biologically active compounds.

Yeasts can be enriched with selenium, iron, copper, and so forth by adding mineral respective salts into the culture medium, although high concentrations of these compounds can inhibit cell growth (Arakaki et al., 2011; Gaensly et al., 2011; Martiniano et al., 2016). Selenium is a non-metal with an important antioxidant role, protecting against free radicals and several diseases. The consumption of Se-enriched yeast biomass has demonstrated better results in animal health when compared with the consumption of inorganic selenium 
TABLE 2 | Agroindustrial byproducts and wastes used as feedstocks for single-cell protein from yeasts and the obtained maximum protein (\%) and maximum cell biomass $(\mathrm{g} / \mathrm{L})$.

\begin{tabular}{|c|c|c|c|c|}
\hline Feedstock & Microorganism & Protein (\%) & Biomass (g/L) & References \\
\hline $\begin{array}{l}\text { Sugarcane bagasse } \\
\text { hemicellulosic hydrolysate }\end{array}$ & Candida tropicalis & 60.05 & 16.97 & Magalhães et al., 2018 \\
\hline Bamboo wastewater & Candida utilis & N/A & 19.17 & Li et al., 2009 \\
\hline $\begin{array}{l}\text { Black liquor from soda pulping } \\
\text { process }\end{array}$ & C. utilis & 39.82 & 12.6 & Hu et al., 2015 \\
\hline Waste cabbage juice & $\begin{array}{l}\text { C. utilis, Kluyveromyces } \\
\text { marxianus, Pichia stipitis, and } \\
\text { Saccharomyces cerevisiae }\end{array}$ & 30 & 11 & Choi and Park, 2003 \\
\hline $\begin{array}{l}\text { Wheat gluten hydrolysate and } \\
\text { soy protein hydrolysate }\end{array}$ & Saccharomyces pastorianus & N/A & 9.23 and 9.85 & Xu et al., 2019 \\
\hline Wheat bran & $\begin{array}{l}\text { C. utilis and Rhizopus } \\
\text { oligosporus }\end{array}$ & 41 & $\mathrm{~N} / \mathrm{A}$ & Yunus et al., 2015 \\
\hline Sugarcane bagasse & S. cerevisiae & 13.41 & N/A & Samadi et al., 2016 \\
\hline Raw glycerol from rapeseed oil & Yarrowia lipolytica & 46.1 & 21.3 & Juszczyk et al., 2019 \\
\hline $\begin{array}{l}\text { Salad oil manufactured } \\
\text { wastewater }\end{array}$ & $\begin{array}{l}\text { C. tropicalis, C. utilis, Candida } \\
\text { boidinii, Rhodotorula rubra, and } \\
\text { Trichosporon cutaneum }\end{array}$ & 26 & 3.2 & Zheng et al., 2005 \\
\hline Bread waste hydrolysate & S. cerevisiae (commercial) & N/A & 25 & Benabda et al., 2018 \\
\hline Parboiled rice effluent & Saccharomyces boulardii & $\mathrm{N} / \mathrm{A}$ & 3.8 & Gaboardi et al., 2018 \\
\hline
\end{tabular}

N/A, not available.

(Berntssen et al., 2017; Emamverdi et al., 2018; Falk et al., 2019), but owing to growth inhibition, most studies have utilized chemically defined medium or hydrolysates from byproducts rich in simple sugars (Esmaeili et al., 2012; Sánchez-Martínez et al., 2012). However, recently, a patent applied by Martiniano et al. (2016) demonstrated the potential of lignocellulosic and starchy agroindustrial byproducts as feedstocks for selenium enrichment in GRAS yeasts, demonstrating that vegetal biomasses can be utilized as inexpensive sources of carbohydrates and protein for the generation of enriched yeasts. Thus, the production of SCP from agroindustrial byproducts can be associated with mineral enrichment, provided that medium composition and fermentative conditions enable cell growth, contributing to the development of alternative eco-friendly technologies.

\section{Oleaginous Yeasts}

Oleaginous yeasts belong to a group of microorganisms that contain lipid content greater than 20\% (dry weight), although some can produce over $60 \%$ of their dry mass, primarily in triglyceride forms (Donot et al., 2014; Lopes et al., 2018; Martinez-Silveira et al., 2019). Two metabolic pathways are involved in this process depending on the type of substrate applied. In hydrophobic substrates, the lipid production occurs along with cell growth, while hydrophilic substrates are biomodified (Donot et al., 2014; Lopes et al., 2018). The lipid accumulation by yeasts is directly dependent on medium composition, requiring nitrogen limitation and generally starting after the end of cell growth until the depletion of carbon sources, resulting in the conversion of substrate into oils (Christophe et al., 2012; Madani et al., 2017).

In general, unsaturated fatty acids correspond to over $40 \%$ of lipid content in yeasts, which are also able to produce polyunsaturated fatty acids and lipids rarely present in plants, some of them with dietetical and medical relevance (Papanikolaou and Aggelis, 2011; Donot et al., 2014; Lopes et al., 2018). The common and abundant fatty acids in oleaginous yeasts are oleic (18:1), stearic (18:0), palmitic (16:0), and linoleic (18:2) acids, although their concentrations vary according to each substrate and yeast strain. Owing to their high content and composition, microbial oils are considered good alternative sources of triglycerides for biodiesel production (Martinez-Silveira et al., 2019).

Microorganisms have the ability to accumulate high concentrations of oil and to grow fast and do not require much space to grow; moreover, they are more resistant to weather changes, when compared with plants (Santori et al., 2012; Yaşar, 2020). Oleaginous yeasts also have the ability to grow in various carbon sources, including wastes (Papanikolaou and Aggelis, 2011), which enables the use of different agroindustrial substrates, such as lignocellulosic biomass, starchy byproducts, urban wastes, and waste oils. Moreover, the use of wastes as feedstock does not directly compete with food production and also might be an alternative treatment for these residues.

Fermentative processes using waste oils, that is, hydrophobic substrates, enabled over $30 \%$ of lipid accumulation by yeasts in dry weight. Louhasakul et al. (2018) studied the use of palm oil mill effluent added with crude glycerol under nitrogen limitation as a substrate for yeasts $Y$. lipolytica and C. tropicalis, achieving a lipid content of 52.7 and $33.5 \%$, respectively, and protein contents of about $20 \%$. Fatty acid profiles of these microorganisms were composed of $46.8 \%$ oleic acid in C. tropicalis, whereas palmitic acid was the main lipid in $Y$. lipolytica, corresponding to $49.8 \%$. Lopes et al. (2018) evaluated the use of pork lard as a substrate for the growth of Y. lipolytica with lipid accumulation of $58 \%$, predominantly in the form of oleic $(35-53 \%)$ and palmitic (25-48\%) acids, followed by linoleic (3-22\%) and stearic 
(2-21\%) acids, demonstrating a bio-modification of substrate by increasing its intracellular palmitic and oleic acid content when compared with the animal fat. In another study, also with Y. lipolytica, Juszczyk et al. (2019) produced cell biomass containing $48.2 \%$ protein and $30.51 \%$ lipids, mainly represented by oleic, palmitic, and linoleic acids using raw glycerol from rapeseed oil. The lipid production by yeasts from oils and fats is not growth associated and does not depend on nitrogen limitation, being related to the substrate composition (Donot et al., 2014). Thus, the use of waste oils might be a low-cost feedstock, because yeasts are able to grow in different substrates and to perform a bio-modification of initial fatty acids content into a high value-added product.

Agroindustrial residues, mainly lignocellulosic biomass, are also applied for the growth of oleaginous yeasts. Antonopoulou et al. (2020) utilized dried sweet sorghum stalks as a substrate for single-cell oil associated with ethanol production by Trichosporon fermentans; the results revealed that the substrate supported yeast growth and lipid accumulation, with no requirement of a nitrogen source. Nevertheless, the authors observed that an enzymatic saccharification step in sorghum stalks increases lipid production by improving C: $\mathrm{N}$ ratio in the medium. T. fermentans presented $11.5 \%(\mathrm{w} / \mathrm{w})$ of lipid, primarily composed of oleic (37.9\%), palmitic (23\%), and linoleic (19.5\%) acids. In another study, paddy straw hydrolysate was evaluated as feedstock for Trichosporon mycotoxinivorans, achieving a lipid content of about 35\% (dry weight), composed of oleic (30.84\%), palmitic (18.28\%), and stearic (17.64) acids as the main fatty acids (Sagia et al., 2020). Sugarcane bagasse hemicellulosic hydrolysate was utilized for the growth of Rhodotorula mucilaginosa with two stages in the fed-batch process altering C:N ratio to initially increase cell growth and subsequently lacks nitrogen, resulting in of $5.35 \mathrm{~g} / \mathrm{L}$ of cell biomass and $25.3 \% \mathrm{w} / \mathrm{w}$ lipid accumulation (Bandhu et al., 2019).

Among hydrophobic substrates, starchy byproducts can be also used for yeast growth and lipid production. Chaturvedi et al. (2019) studied several agroindustrial wastes (wheat bran, corn residue, potato peel, cassava peel, yam peel, banana peel, barley husk, and rice husk) for the growth of yeasts like Cryptococcus curvatus, Lipomyces starkeyi, Trichosporon cutaneum, R. mucilaginosa, Rhodotorula glutinis, and S. pastorianus. The highest lipid accumulation (52.04\% of dry mass) was found with L. starkeyi, which produced $26.71 \mathrm{~g} / \mathrm{L}$ of cell biomass when cultivated in rice residue, whereas wheat bran allowed the highest cell biomass production $(61.0 \mathrm{~g} / \mathrm{L})$ with $R$. mucilaginosa and $4.92 \% \mathrm{w} / \mathrm{w}$ lipid content. Likewise, in another study, wheat bran and corn bran hydrolysates were used as substrate for L. starkeyi with major lipid production of $37.3 \% \mathrm{w} / \mathrm{w}$, mainly composed of oleic acid (70\%) and $17.1 \mathrm{~g} / \mathrm{L}$ of cell biomass (Probst and Vadlani, 2015). Most of plant hydrolysates are hydrophilic substrates and do not require the addition of nitrogen sources, considering that single-cell oil production by oleaginous yeasts requires a nitrogen limitation in the fermentative medium. Furthermore, the prevalence of oleic acid provides an additional value to the product (Probst and Vadlani, 2015), as well as other fatty acids with important health benefits (Papanikolaou and Aggelis, 2011; Donot et al., 2014; Lopes et al., 2018).

\section{Biopigments}

Historically, the first substances that were used by humankind with the specific purpose of giving color to a material (i.e., colorants) were provided by natural sources, such as roots, berries, and flowers. However, this scenario completely changed at the end of the 19th century, when the first artificial dye, mauveine, was synthesized. With the development of organic chemistry, a variety of synthetic dyes have been produced, and the cost of production of such molecules was greatly reduced, decreasing the need for natural dyes (biopigments) and limiting their availability on the market.

From an economic perspective, biopigments are still less competitive than synthetic pigments. As an example, the synthetic form of astaxanthin, one of the most valued carotenoids, is sold for USD 2,500/kg, whereas its natural source costs USD 7,000/kg (Ambati et al., 2019). The current scenario presents two features that indicate that achieving high levels of biopigment production associated with lower market costs is imperative: consumer's demand for biopigments has been increasing, and in the last decades, a considerable number of synthetic colorants have been banned as a result of their hazardous effects (Goswami et al., 2015; Rao et al., 2017; Ambati et al., 2019).

Comparisons between natural pigments and their synthetic counterparts should not only be limited to their economic aspects, but their biological activities and nutraceutical facets should also be compared. It is well known that biopigments present a better performance regarding health properties than their synthetic versions, for example, antioxidant activity and radical trapping (Murthy et al., 2005; Capelli et al., 2013). More research focusing on the biological activities of natural and synthetic pigments as well as its toxicity and bioavailability should be conducted in order to facilitate regulatory issues and market appraisal of biopigments.

Biopigments are produced by a variety of plants, but there is also a great number of microbial species that produce these compounds, such as fungi, yeasts, algae, and bacteria. Generally, it is considered that microbial synthesis of biopigments is more feasible as compared with plant especially because of the possibility to achieve high yields in a reduced space and its independence from seasonal factors. However, the elevated cost of the synthetic substrates that are commonly used in such bioprocesses reduces the economic feasibility of these biotechnological ways. As an option to overcome this obstacle, agricultural byproducts have entered the game (Freitas et al., 2014; Mata-Gómez et al., 2014; Rao et al., 2017).

The majority of agricultural byproducts are represented by plant biomass, which are considered as the largest reservoir of carbon on Earth (Jurado et al., 2011). Agroindustrial byproducts have been employed for the production of biopigments; to date, a large variety of byproducts have been used for this purpose (Table 3).

Byproducts from the coffee industry were successfully applied for the production of biopigments. Moreira et al. (2018) evaluated 
TABLE 3 | Examples of recent researches focusing on the production of biopigments employing agroindustrial byproducts.

\begin{tabular}{|c|c|c|}
\hline $\begin{array}{l}\text { Agroindustrial } \\
\text { byproduct }\end{array}$ & Biopigment & References \\
\hline $\begin{array}{l}\text { Orange processing } \\
\text { waste }\end{array}$ & Monascus pigments & Kantifedaki et al., 2018 \\
\hline Coffee husk and pulp & Carotenoids & Moreira et al., 2018 \\
\hline $\begin{array}{l}\text { Corn steep liquor, } \\
\text { sugarcane molasses } \\
\text { and raw glycerol }\end{array}$ & Carotenoids & Rodrigues et al., 2019 \\
\hline $\begin{array}{l}\text { Corn steep liquor and } \\
\text { parboiled rice waste }\end{array}$ & Carotenoids & Colet et al., 2015 \\
\hline $\begin{array}{l}\text { Rice straw and crude } \\
\text { glycerol }\end{array}$ & Carotenoids & Yen et al., 2015 \\
\hline Wheat wastes & Astaxanthin & Dursun and Dalgıç, 2016 \\
\hline Malt bagasse & Monascus pigments & Hamano and Kilikian, 2006 \\
\hline $\begin{array}{l}\text { Carob pulp syrup and } \\
\text { sugarcane molasses }\end{array}$ & Carotenoids & Freitas et al., 2014 \\
\hline $\begin{array}{l}\text { Rice husk, grape } \\
\text { waste, soybean } \\
\text { protein, soybean meal, } \\
\text { pig hair, chicken } \\
\text { feathers, feather meal, } \\
\text { fish meal, cheese whey }\end{array}$ & $\begin{array}{l}\text { Yellow pigments, } \\
\text { monascorubrin, and } \\
\text { rubropunctatin }\end{array}$ & Lopes et al., 2013 \\
\hline Cassava wastewater & Carotenoids & Santos-Ribeiro et al., 2019 \\
\hline
\end{tabular}

the use of coffee husk and pulp extract as nutrient sources for the production of biopigments using yeast $R$. mucilaginosa. Further, it was verified that the produced pigment is carotenoids and that it presented antioxidant and antimicrobial activities. Similarly, spent coffee grains were also employed in a bioprocess involving the yeast Sporobolomyces roseus, and it was observed that the maximum carotenoid concentration was $12.59 \mathrm{mg} / \mathrm{L}$, supporting the feasibility of the production of enriched yeast biomass by the utilization of this byproduct (Petrik et al., 2014).

Santos-Ribeiro et al. (2019) proposed the use of cassava wastewater as a sole nutrient source for the cultivation of R. glutinis. The results recorded showed elevated values of cell concentration $(10.28 \mathrm{~g} / \mathrm{L})$, carotenoids $(0.98 \mathrm{mg} / \mathrm{L})$, and lipids $(1.34 \mathrm{~g} / \mathrm{L})$.

Another favorable approach that has been investigated for the production of biopigments is the combination of different agroindustrial byproducts in a complex culture medium. For instance, Colet et al. (2017) elaborated a combination of parboiled rice water, crude glycerol, and corn maceration water for growth and carotenoid production by Sporidiobolus salmonicolor in a semicontinuous system. The authors verified that the operation of this biotechnological process in a semicontinuous system helps to increase the carotenoid production by nearly $55 \%$ than does a fed-batch process (Colet et al., 2015).

Besides the enormous versatility of plant biomass for the production of biopigments through biotechnological approaches, wastewaters from food and beverage industries are also an asset for this field. The high values of biological oxygen demand (BOD) and chemical oxygen demand (COD) presented by such effluents represent a complication to their disposal, however, it is a beneficial for some microbes. $\beta$-Carotene was successfully produced by the yeast $R$. glutinis as a brewery waste (Schneider et al., 2013), whereas $R$. mucilaginosa carotenoids were obtained in a culture medium based on rice parboiling wastewater and other agricultural byproducts (Rodrigues et al., 2019).

Some carotenigenic yeasts are also remarkable oil producers; therefore, agroindustrial byproducts can be employed as substrates for the generation of both biopigments and microbial oil. For instance, microbial oil and carotenoids were obtained simultaneously by oleaginous yeast (R. glutinis and Rhodotorula gracilis) grown on cassava wastewater (Santos-Ribeiro et al., 2019) and potato wastewater combined with raw glycerol (Kot et al., 2020). Single-cell oil is an expensive biomolecule, especially in a biorefinery context, because fatty acids and glycerol can be used as precursors of a wide range of value-added products, such as biodiesel, emulsifiers, and polymers (Jin et al., 2015). Hence, it is interesting to explore bioprocesses for the generation of biopigments and microbial oils with the employment of agricultural byproducts and also to study scaling-up processes.

Along with the environmental and economic benefits of biopigment production from agroindustrial byproducts, it must be highlighted that many of these valuable molecules not only have coloring property but also present crucial bioactivities such as anti-inflammatory, antimicrobial, and antitumor activities; free radical scavenging; and antioxidant activity. Moreover, specific biopigment such as carotenoids can also be used as provitamin A. The filamentous fungi Monascus has been extensively cultivated both in solid state and in submerged cultivation systems for the production of biopigments like rubropunctatin and monascorubrin, which have potential antimicrobial activity, whereas other pigments from this fungus have displayed anticholesterolemic effects and antitumor activity (Patakova, 2013).

One of the most essential biological properties to human health is the antioxidant activity, which helps in the prevention of numerous diseases (cancer, eye conditions, liver problems, etc.) (Stahl et al., 1997; Hernández-Almanza et al., 2014; Dursun et al., 2016; Barredo et al., 2017). Carotenoids are recognized as an important group of antioxidants, and they are included in the human diet by daily consumption of vegetables (e.g., carrot, tomato, and pumpkin), but yeasts and fungi are also remarkable producers of these biopigments, which could be obtained in biotechnological facilities, purified, and sold as health supplements.

Carotenoids from three wild yeast species were successfully obtained after cultivation in a series of agroindustrial byproducts (raw glycerol, corn steep liquor, and sugar cane molasses), and the biopigment extracts showed a notorious antioxidant activity (Cipolatti et al., 2019). Promising results were reported by Moreira et al. (2018), where carotenoids extracted from $R$. mucilaginosa CCMA0156 exhibited antioxidant and antimicrobial activities against pathogenic bacteria and fungi. These results demonstrated that there is a vast biotechnological potential that needs a deeper investigation regarding nutraceutical features and biological activities of microbial biopigments.

Most of the studies on production of microbial biopigments utilized agroindustrial byproducts and their hydrolysates with 
commercially available nutrients, such as inorganic salts or purified organic extracts (Schneider et al., 2013; Goswami et al., 2015; Panesar et al., 2015; Cardoso et al., 2016; Liu and Zhu, 2017). Nonetheless, it has been demonstrated that it is possible to obtain microbial growth and biopigment production by elaborating a culture medium composed only of agroindustrial derivative products (Colet et al., 2017; Lin et al., 2019; Urnau et al., 2019; Kot et al., 2020). Because it is well known that agricultural wastes possess a variety of nutrients and micronutrients and that a wide number of microbes that synthesize biopigments are versatile organisms in terms of metabolic activity, it is of great relevance to this field that more studies based exclusively on agroindustrial byproducts need to be developed. In such way, it will be possible to optimize biopigment production by applying sustainable biotechnological strategies and reducing production costs.

Before selection of any agricultural byproducts as sources of nutrients for the production of biopigments, different aspects must be taken into consideration such as availability of the biomass, costs involved in its pretreatment, inhibitors' tolerance of the involved microorganism, and capability of such microorganism of fermenting C5 sugars.

The sugarcane industry is one of the main agribusinesses in the world, and the industrial activities related to sugar and alcohol generation produce mainly three byproducts: bagasse, molasses, and press mud (Sarker et al., 2017; Sahu, 2018). Sugarcane bagasse has been extensively used in biotechnological processes because not only of its low cost and great availability but also of its rich composition. Data available in literature presented that this byproduct is predominantly composed of glucan (40$50 \%)$, hemicellulose (17-30\%), lignin (20-25\%), ash (1-4\%), and extractives (4-9\%) (Szczerbowski et al., 2014). Like other bioproducts, biopigments can also be produced using sugarcane bagasse through both submerged and solid-state fermentations.

Pigments from the filamentous fungus Monascus ruber were successfully obtained in a culture media based on sugarcane bagasse hydrolysate. Terán-Hilares et al. (2018) demonstrated that under dark conditions, sugarcane bagasse hydrolysate inoculated with $M$. ruber resulted in a higher amount of red pigment production compared with a glucose-based culture medium. The authors also observed the recovered pigments presented significant thermal stability.

Sugarcane bagasse hydrolysate was also indicated as a feasible carbon source for the yeast Phaffia rhodozyma, which was able to metabolize its main sugars, resulting in favorable cell yield. Furthermore, this research demonstrated the importance of studying the effect and optimizing the C:N ratio regarding the biotechnological production of biopigments, especially when dealing with complex hydrolysates, because the use of this renewable carbon source resulted in a lower cell-specific productivity when compared with reagent-grade sugar solutions (Montanti et al., 2011).

Sugarcane molasses is a byproduct with a complex composition: nearly $50 \%$ of sugars (mainly glucose, sucrose, and fructose) and low levels of lipids, proteins, vitamins, organic acids, and heavy metals (Freitas et al., 2014; Liu and Zhu, 2017). The main employments of this byproduct are energy generation, ethanol and organic acid production, animal feeding, raw materials for rum production, and ingredients of some foods (Sindhu et al., 2016).

Molasses is a favorable substrate for the production of biopigments by different species of yeasts, however, it has also limitations. During the production of carotenoids by the yeast Rhodosporidium toruloides, using sugarcane molasses as substrate, it was reported that its high concentration inhibits cell growth (Freitas et al., 2014). Moreover, some studies on the production pigments involving the use of yeasts and agroindustrial byproducts as nutrient sources are presented in Table 4.

Rodrigues et al. (2019) studied the production of biopigment and cell concentration using sugarcane molasses and yeast R. mucilaginosa CCT7688. The results obtained indicated that there was a significant increase in carotenoid production and cell concentration with increase in the amount of sugarcane molasses. Moreover, it was also reported that the combined use of corn steep liquor and sugarcane molasses in a fed-batch fermentation system can increase the total carotenoid production by $400 \%$ when compared with the batch processes, demonstrating the biotechnological feasibility of reducing production costs of highvalued compounds by incorporating an agroindustrial byproduct to the process. As discussed above, yeasts and fungi that produce biopigments are versatile organisms in the context of substrate utilization and environmental parameters and, furthermore, are able to produce a variety of high-valued molecules. Despite of these features and the expressive amount of studies involving sugarcane processing byproducts and biopigment production, there is few literature regarding biorefinery concepts for the production of biopigments from yeasts or filamentous fungi (Ferreira et al., 2016; Routray et al., 2019; Parsons et al., 2020).

Other interesting alternative raw materials include rice, soybean, and wheat bran that resulted from the milling processes of these materials. The protein content in rice and wheat bran is nearly $15 \%$, whereas for soybean bran, it ranges from 40 to 50\% (Tsigie et al., 2012; Prückler et al., 2014; Zhang et al., 2015). The high protein percentage in such byproducts makes them an attractive source of nitrogen for the production of biopigments, especially carotenoids, because some researches pointed out that the use of complex nitrogen sources and low C:N ratio favors the synthesis of these metabolites (Bhosale and Gadre, 2001; El-Banna et al., 2012).

Monascus species have been grown on rice to obtain fermented foods (e.g., angkak rice) for many centuries (Lin et al., 2008), and the knowledge acquired from traditional techniques was the basis for many biotechnological types of research based on byproducts from the rice agroindustry. As an example, Singh et al. (2015) optimized a culture medium based on rice water and ammonium nitrate for pigments by Monascus purpureus MTCC369 and the best red pigment yield (20.44 $\mathrm{U}$ abs of $500 \mathrm{~nm} / \mathrm{mg}$ of dry fungus biomass) was measured when the only medium component was rice water.

Similarly, rice bran is also a versatile product for biotechnological applications, and according to Roadjanakamolson and Suntornsuk (2010), it is possible to produce $\beta$-carotene-enriched rice bran, especially for animal 
TABLE 4 | Biopigment production using different corn byproducts.

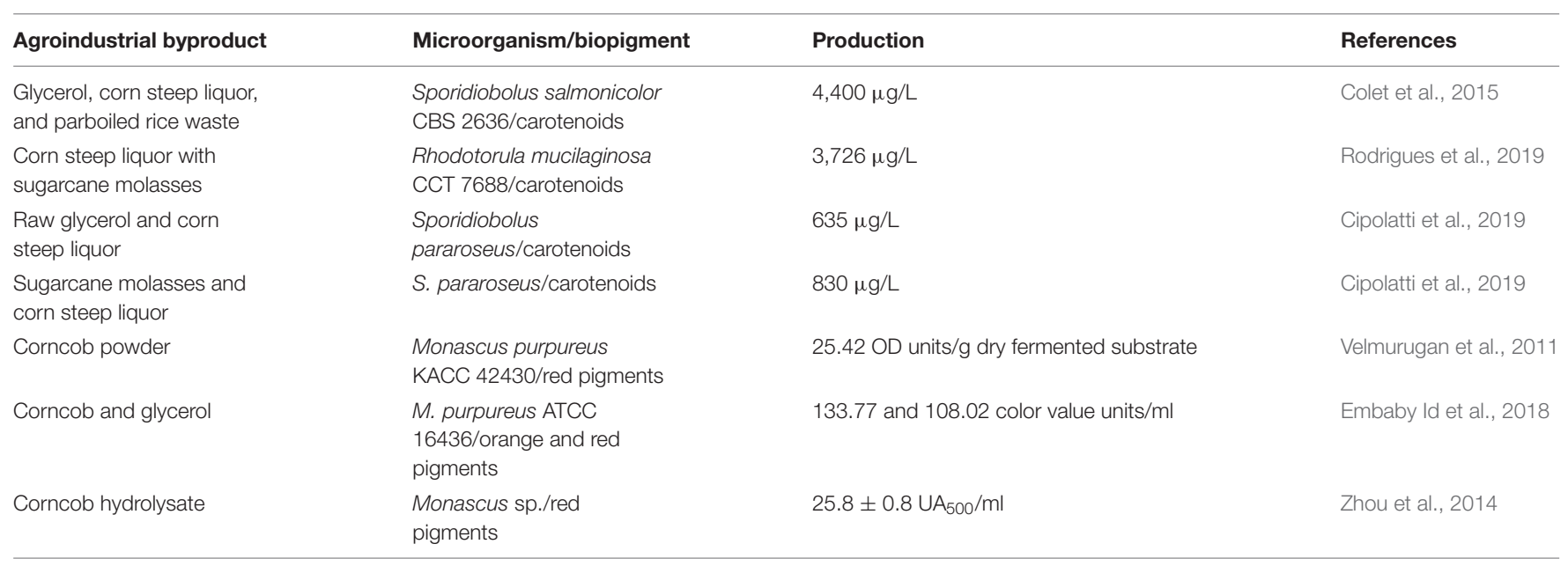

feeding, by utilizing it as a solid substrate for the yeast $R$. glutinis. Moreover, it was also reported that the type of feedstock plays an important role in biopigment production, because $\beta$-carotene production was found to be reduced when a byproduct like sugarcane molasses and bagasse is used.

Likewise, biopigment production employing byproducts from wheat processing is another interesting approach. Wheat straw hemicellulosic and cellulosic hydrolysates were evaluated as carbon sources for carotenoid production by $R$. toruloides NRRL Y-1091, and the feasibility of this proceeding was related to efficient detoxification of the hydrolysates by a low-cost method, a key parameter for the scaling-up of the process (Liu et al., 2020). Another significant research was conducted by Dursun and Dalg1ç (2016), and it was based on the production of a highly valued carotenoid, astaxanthin, by different yeast species (Yamadazyma guilliermondii, Y. lipolytica, Xanthophyllomyces dendrorhous, and S. salmonicolor) in solidstate cultivation.

By comparing red pigment production of $M$. purpureus CMU 001 in different agroindustrial wastes, Nimnoi and Lumyong (2011) observed that cornmeal gave better production results (19.4 U/gds) than did peanut meal, coconut residue, and soybean meal and that it was possible to increase the process yield by supplementing this material with soybean meal (22.50 U/gds), peanut meal (52.50 U/gds), and coconut residue $(63.50 \mathrm{U} / \mathrm{gds})$.

\section{Biosurfactants}

In the last few years, the natural surfactants or BSs have been highlighted in academic studies and various industries owing to their versatility and properties. BSs are molecules produced by animals (pulmonary surfactants and bile salts), plants (saponins), and microorganisms that present tensoactive and/or emulsifier properties (Shekhar et al., 2015). Besides, some studies reported antimicrobial, antitumor, algicidal, larvicidal, and insecticidal activities for these compounds (Wu et al., 2017; FrancoMarcelino et al., 2017; Liu et al., 2019). These biomolecules are considered eco-friendly or green compounds owing to their high biodegradability, low or non-toxicity, and biocompatibility, not causing risks to the environment and animals, plants, and humans (Fenibo et al., 2019).

Among the natural surfactants, most of the studies are developed with the microbial BSs, because microorganisms present faster and greater productivity than do plants. The members of genus such as Pseudomonas and Bacillus have been recognized as good BS producers, however, owing to their nonGRAS status, the BSs produced by those bacteria have restricted applications, especially in the food and pharmaceutical industries (Barth and Gaillard, 1997; Fontes et al., 2008). On the other hand, yeasts used for BS production have GRAS status and present cell structures that are more resistant to the secreted BSs in the culture medium when compared with bacteria, making them more attractive for the industrial production of these metabolites (Monteiro et al., 2009).

Microbial BSs are classified in glycolipids, lipopeptides/lipoproteins, polymerics, phospholipids, neutral fat acids, and complexes. Some studies also report the production of BSs of the nucleolipid type by some bacteria (Isono et al., 1985). The most common and applied microbial BSs, mainly in the food chemical, pharmaceutical, and cosmetic industries, are glycolipids and lipopeptides/lipoproteins, such as rhamnolipids (RML), sophorolipids (SPL), mannosylerythritol lipids (MEL), and surfactin (SUF) (Santos et al., 2016). Figure 3 shows the main produced BSs in the world and their applications.

The physical, chemical, and biological properties of BSs facilitate their use in several sectors for different applications. BSs like glycolipids are usually used as feed additives, food emulsifiers (to replace lecithins, which cause allergies in many people), drug delivery nanosystems for the treatment of various diseases, formulations of oral care products, adjuvant agents in vaccines, and biopesticides; for seed treatment and coating; and in the development of polymers aiming for paint formulations for 3D printing (Gao et al., 2007; Naughton et al., 2019). From the wide range of applications of BSs, it can be considered as one of the important high value-added products in biorefineries. However, it is also noteworthy that the BSs produced in biorefineries using agroindustrial byproducts for application in the food and pharmaceutical industries require high-cost downstream 


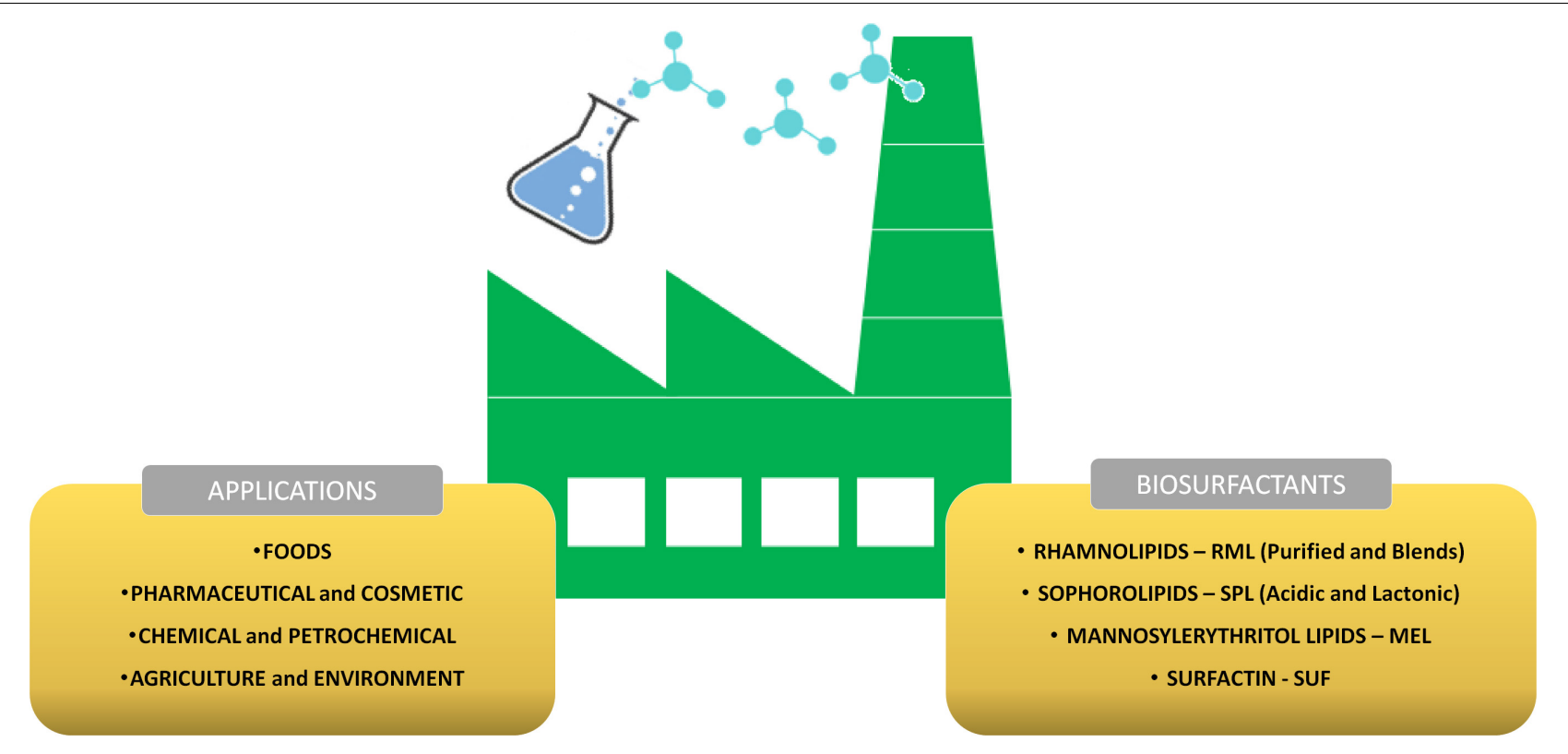

FIGURE 3 | Main BS-producing companies in the world and their applications. BS, biosurfactants.

methods that guarantee greater purity of the final product, making the product more expensive. On the other hand, BSs used for agricultural purposes do not require severe purification processes, reflecting on the costs of the final product.

Despite the versatility and advantages of BSs, the production of these compounds has, until now, low viability, because the process costs are high, reflecting on the final price of the products. According to Cameotra and Makkar (1998), raw materials represent up to $30 \%$ of the costs of a bioprocess. An alternative to minimize this problem is the use of industrial byproducts as raw materials in BS production. Billions of tons of byproducts are produced every year in agriculture and agroindustries. Owing to the presence of macroelements and microelements, such as protein, lipids, carbohydrates, vitamins, and mineral salts, the agroindustrial byproducts are considered potential raw materials for the BS production (Makkar et al., 2011; Torres-León et al., 2018).

The BS fermentation process generally uses oils and oily byproducts from the food industries and glycerin from the biodiesel industry as raw materials (Makkar et al., 2011; Bhardwaj et al., 2013; Table 5), but byproducts rich in carbohydrates, such as molasses, are also used in BS production (Tan and $\mathrm{Li}$, 2018). Generally, the BS fermentation uses oily (hydrophobic) byproducts combined with sugars or sugary (hydrophilic) byproducts as carbon sources, as a strategy to increase the yield (Fontes et al., 2008).

Some lignocellulosic byproducts have been used for the production of BSs. The use of different biomasses as raw materials for the production of hemicellulosic hydrolysates for BS generation is described in the literature, such as trimming vine shoots (Bustos et al., 2005), barley bran, corncobs and Eucalyptus globulus (Moldes et al., 2006), distilled grape marc (PortillaRivera et al., 2007), sweet sorghum bagasse hydrolysate (Samad et al., 2014), orange peel (Kumar et al., 2016), sugarcane bagasse (Franco-Marcelino et al., 2017; Marcelino et al., 2019), waste office paper (Nair et al., 2018; Nair et al., 2020), and xylose-rich corncob hydrolysate (Chen et al., 2019).

Among the main problems in the use of lignocellulosic byproducts as raw materials for the production of BSs in biorefineries are the presence phenolic compounds and metals generated after the pretreatment, which can inhibit the microbial growth and reduce the bioprocess yield (Santos et al., 2018). To solve the toxicity problem of hydrolysates, resistant engineered microorganisms and acclimatization methods for wild microorganisms can be applied. The use of genetically modified microorganisms, although extensively studied, presents as a main problem the instability of the strain along industrial bioprocesses. The acclimatization of microorganisms, despite being a simpler and slower technique, usually brings good results as it presents viable costs.

The production of BSs using agroindustrial byproducts as raw materials is still underexplored, however, it is attractive for lignocellulosic biorefineries because BSs are products with high added value. Further studies for the development of this promising technology (bioreactors, medium composition, and fermentation conditions) are required as well as the technical and economic feasibilities of these sustainable processes and products.

\section{Challenges and Way Forward in the Development of Biorefinery}

As far as the challenges in the development of biorefinery are concerned, there are many significant barriers to the elaboration of a self-sufficient biorefinery industry (Fernando et al., 2006). Some of these barriers are briefly enlisted in the Introduction. 
TABLE 5 | Raw materials used in BS production.

\begin{tabular}{|c|c|c|}
\hline $\begin{array}{l}\text { Raw } \\
\text { materials/carbon } \\
\text { sources }\end{array}$ & Biosurfactant (BS) produced & References \\
\hline $\begin{array}{l}\text { Animal fat and } \\
\text { glucose }\end{array}$ & Glycolipid & $\begin{array}{l}\text { Deshpande and } \\
\text { Daniels, } 1995\end{array}$ \\
\hline Potato waste & Lipopeptide/lipoprotein & $\begin{array}{l}\text { Thompson et al., } \\
2001\end{array}$ \\
\hline $\begin{array}{l}\text { Oil refinery residual } \\
\text { hydrocarbons }\end{array}$ & Glycolipid & $\begin{array}{l}\text { Bednarski et al., } \\
2004\end{array}$ \\
\hline Corn oil & Glycolipid & $\begin{array}{l}\text { Pekin and } \\
\text { Vardar-Sukan, } \\
2005\end{array}$ \\
\hline Glycerol & Glycolipid & Morita et al., 2007 \\
\hline $\begin{array}{l}\text { Waste from } \\
\text { vegetable oil } \\
\text { industries }\end{array}$ & Complex BS & Rufino et al., 2007 \\
\hline Residual cooking oil & Glycolipid & $\begin{array}{l}\text { Shah et al., 2007; } \\
\text { Yañez-Ocampo } \\
\text { et al., } 2017\end{array}$ \\
\hline Soy molasses & Glycolipid & $\begin{array}{l}\text { Solaiman et al., } \\
2004,2007\end{array}$ \\
\hline $\begin{array}{l}\text { Waste from } \\
\text { soybean oil } \\
\text { industries }\end{array}$ & & Rufino et al., 2008 \\
\hline Peanut oil & Glycolipid & $\begin{array}{l}\text { Sobrinho et al., } \\
\text { 2008; Coimbra } \\
\text { et al., } 2009\end{array}$ \\
\hline Soybean oil & Not identified & $\begin{array}{l}\text { Thaniyavarn et al., } \\
2008\end{array}$ \\
\hline $\begin{array}{l}\text { Cane molasses and } \\
\text { residual soybean oil }\end{array}$ & Glycolipid & $\begin{array}{l}\text { Daverey and } \\
\text { Pakshirajan, } 2009\end{array}$ \\
\hline $\begin{array}{l}\text { Dairy industry } \\
\text { effluents }\end{array}$ & Glycolipid & $\begin{array}{l}\text { Monteiro et al., } \\
2009\end{array}$ \\
\hline $\begin{array}{l}\text { Deproteinized whey } \\
\text { and glucose }\end{array}$ & Glycolipid & $\begin{array}{l}\text { Daverey and } \\
\text { Pakshirajan, } 2009\end{array}$ \\
\hline $\begin{array}{l}\text { Waste from } \\
\text { vegetable oil } \\
\text { industries }\end{array}$ & Glycolipid & $\begin{array}{l}\text { Gusmão et al., } \\
2010\end{array}$ \\
\hline Glycerol & Glycolipid & Liu et al., 2011 \\
\hline $\begin{array}{l}\text { Molasses/cheese } \\
\text { whey }\end{array}$ & Glycolipid & $\begin{array}{l}\text { Anandaraj and } \\
\text { Thivakaran, } 2010\end{array}$ \\
\hline $\begin{array}{l}\text { Biodiesel refinery } \\
\text { (waste glycerol) }\end{array}$ & Complex BS & $\begin{array}{l}\text { Monteiro et al., } \\
2012\end{array}$ \\
\hline Glycerol & Glycolipid & Bezerra et al., 2019 \\
\hline Coffee wastewater & Lipopeptide/lipoprotein & $\begin{array}{l}\text { Yañez-Ocampo } \\
\text { et al., } 2017\end{array}$ \\
\hline
\end{tabular}

However, the technological challenges are presented as the most relevant issue among the presented barriers, because most of the currently used biorefining technologies are very old and directly affect the production yield of generated products in the biorefinery. The conventional techniques like pretreatment methods used for various feedstocks and enzymatic hydrolysis have many disadvantages, like low efficiency and operational high cost. Moreover, apart from these, various other challenges affect the success of integrated biorefinery, including political and market resistance, and a lack of supporting infrastructure such as feedstock, fuels, and transportation.
Besides, market development and penetration issues are also major concerns ${ }^{1}$.

Therefore, overcoming these barriers is the only way forward to make the biorefinery self-sufficient. The technological challenges are usually addressed through the development of novel technological solutions by proper research. There is an urgent need to develop novel, eco-friendly, and economically viable technologies. The conventional pretreatment methods should have other alternatives. Some of the studies revealed that nanotechnology can be effectively used in the development of promising pretreatment methods with the help of specific nanomaterials (Ingle et al., 2020a,b). Similarly, the disadvantages associated with another step involved in biofuel production, that is, enzymatic hydrolysis, can be managed using nanotechnology. The immobilization of enzymes involved in the enzymatic hydrolysis on magnetic nanoparticles facilitates the repeated use of the same enzyme for multiple cycles of hydrolysis, which ultimately helps to reduce the cost involved in the process (Rai et al., 2019). Therefore, such novel and worthy technological solutions should be implemented after an extensive investigation for higher production yield at a lower cost. Apart from these, other challenges related to feedstock cost, transportation, and so forth can be managed through efficient improvements throughout the supply chain along with supporting analysis. Similarly, problems associated with political and market resistance should be addressed by making effective policies and implementing them at different levels.

\section{CONCLUSION}

The increasing demand for various biorefining biobased products and environmental policy has strongly recommended the recycling and reuse of materials. In this context, the utilization of agroindustrial byproducts or residues has attracted a great of attention from the scientific community considering their rich nutrient contents and bioactive compounds. Different agroindustrial byproducts contain a variety of sugars, minerals, and proteins, and hence, they are considered as potential "raw material" instead of "wastes" for biorefining processes. In this context, adequate pretreatment must be chosen for each utilized biomass, aiming at the proper release of sugars and other nutritional molecules and promoting the adequate media elaboration and generation of several biobased products like biopolymers, nutritional yeast, biopigments, and BSs. The nutrients present in such byproducts can be used as an effective medium for the prolific growth of microorganisms, which consequently helps in the production of high-value biobased biorefining products. It is true that to obtain the required nutrients for fermentation processes using agroindustrial byproducts as raw material, preprocessing or pretreatment of these byproducts is necessary. Some of the conventional approaches have been commonly used for such treatments, but owing to their certain limitations, there is a necessity to develop novel, environment-friendly, and cost-effective alternative

\footnotetext{
${ }^{1}$ https://www.energy.gov/
} 
approaches for effective pretreatment of agroindustrial byproducts. The utilization of agroindustrial byproducts as raw materials can help to reduce the production cost and can contribute to the recycling of waste as well to make the environment eco-friendly. Moreover, it will also help in the successful development of a biobased economy through the biorefinery platforms.

\section{AUTHOR CONTRIBUTIONS}

RP was responsible for "Abstract," "Introduction," and "Biopolymers" sections, figures elaboration, final text, and tables formatting and review. SM was responsible for "Nutritional Yeast" and "Mineral-Enriched Yeasts" section as well as reference standardization, general formatting, and review. AI was responsible for pretreatments section, English formatting, and review. PF and FB was responsible for "Biosurfactants" section, formatting, and general review. GS was responsible for "Biopigments" section, formatting, and general review. JS was

\section{REFERENCES}

Abd-Rahim, M. H., Hasan, H., Lim, E. J., Samrani, P. K., and Abbas, A. (2019). Pretreatment strategies to improve crude glycerol utilization and metabolite production by Aspergillus terreus. Int. J. Chem. Eng. 2019, 1-6. doi: 10.1155/ 2019/2504540

Abdul Raman, A. A., Tan, H. W., and Buthiyappan, A. (2019). Two-step purification of glycerol as a value added by product from the biodiesel production process. Front. Chem. 7:774. doi: 10.3389/fchem.2019.00774

Acosta, S. B. P., Marchioro, M. L. K., Santos, V. A. Q., Calegari, G. C., Lafay, C. B. B., Barbosa-Dekker, A. M., et al. (2020). Valorization of Soybean Molasses as Fermentation Substrate for the Production of Microbial Exocellular $\beta$-Glucan. J. Polym. Environ. doi: 10.1007/s10924-020-01758-z

Akhtar, N., Gupta, K., Goyal, D., and Goyal, A. (2016). Recent advances in pretreatment technologies for efficient hydrolysis of lignocellulosic biomass. Environ. Prog. Sustain. Energy 35, 489-511. doi: 10.1002/ep.12257

Aktas-Akyildiz, E., Masatcioglu, M. T., and Köksel, H. (2020). Effect of extrusion treatment on enzymatic hydrolysis of wheat bran. J. Cereal Sci. 93:102941. doi: 10.1016/j.jcs.2020.102941

Alvira, P., Tomás-Pejó, E., Ballesteros, M., and Negro, M. J. (2010). Pretreatment technologies for an efficient bioethanol production process based on enzymatic hydrolysis: a review. Bioresour. Technol. 101, 4851-4861. doi: 10.1016/j. biortech.2009.11.093

Ambati, R. R., Gogisetty, D., Aswathanarayana, R. G., Ravi, S., Bikkina, P. N., Bo, L., et al. (2019). Industrial potential of carotenoid pigments from microalgae: current trends and future prospects. Crit. Rev. Food Sci. Nutr. 59, 1880-1902. doi: 10.1080/10408398.2018.1432561

Anandaraj, B., and Thivakaran, P. (2010). Isolation and production of biosurfactant producing organism from oil spilled soil. J. Biosci. Tech. 1, 120-126.

Andrietta, M. G. S., Steckelberg, C., Kitaka, P. R., Goldebeck, R., and Andrietta, S. R. (2017). Yeast from Ethanol Production - Source of SCP (Single Cell Protein). WJRR 4, 87-89.

Antonopoulou, I., Spanopoulos, A., and Matsakas, L. (2020). Single cell oil and ethanol production by the oleaginous yeast Trichosporon fermentans utilizing dried sweet sorghum stalks. Renew. Energy 146, 1609-1617. doi: 10.1016/j. renene.2019.07.107

Arakaki, A., Vandenberghe, L. P. S., Soccol, V. T., Masaki, R., Rosa Filho, E. F., Gregório, A., et al. (2011). Optimization of biomass production with copper bioaccumulation by yeasts in submerged fermentation. Braz. Arch. Biol. Technol. 54, 1027-1034. doi: 10.1590/s1516-891320110005 00021 responsible for "Agroindustrial Byproducts" section, English formatting, and review. SS was responsible for the concept, organization, correction, and final evaluation of this review.

\section{ACKNOWLEDGMENTS}

We would like to thank the Research Council for the State of São Paulo (Fundação de Amparo à Pesquisa do Estado de São Paulo-FAPESP-Process No. 2016/10636-8 and grants Process No. 2016/22086-2 and Process No. 2019/19757-0); the Council for Scientific and Technological Development (Conselho Nacional de Desenvolvimento Científico e Tecnológico-CNPq-Process No. 303943/2017-3 and research grant Process No. 153169/2018-4); and Coordination for the Improvement of Higher Education Personnel (Coordenação de Aperfeiçoamento de Pessoal de Nível SuperiorCAPES) for doctorate scholarships. The authors express their gratitude to PROFIDES - México for their approved bilateral project.

Araújo, D., Freitas, F., Sevrin, C., Grandfils, C., and Reis, M. A. M. (2017). Coproduction of chitin-glucan complex and xylitol by Komagataella pastoris using glucose and xylose mixtures as carbon source. Carbohydr. Polym. 166, 24-30. doi: 10.1016/j.carbpol.2017.02.088

Arruda, P. V., Santos, J. C., Rodrigues, R. C. L. B., Silva, D. D. V., Yamakawa, C. K., Rocha, G. J. M., et al. (2017). Scale up of xylitol production from sugarcane bagasse hemicellulosic hydrolysate by Candida guilliermondii FTI 20037. J. Ind. Eng. Chem. 47, 297-302. doi: 10.1016/j.jiec.2016.11.046

Ascencio, J. J., Chandel, A. K., Philippini, R. R., and da Silva, S. S. (2019). Comparative study of cellulosic sugars production from sugarcane bagasse after dilute nitric acid, dilute sodium hydroxide and sequential nitric acidsodium hydroxide pretreatment. Biomass Convers Bior. doi: 10.1007/s13399019-00547-6

Bandhu, S., Bansal, N., Dasgupta, D., Junghare, V., Sidana, A., Kalyan, G., et al. (2019). Overproduction of single cell oil from xylose rich sugarcane bagasse hydrolysate by an engineered oleaginous yeast Rhodotorula mucilaginosa IIPL32. Fuel 254:115653. doi: 10.1016/j.fuel.2019.115653

Barredo, J. L., García-Estrada, C., Kosalkova, K., and Barreiro, C. (2017). Biosynthesis of astaxanthin as a main carotenoid in the heterobasidiomycetous yeast Xanthophyllomyces dendrorhous. J. Fungi 3:44. doi: 10.3390/jof303 0044

Barrett, E. M., Foster, S. I., and Beck, E. J. (2020). Whole grain and high-fibre grain foods: how do knowledge, perceptions and attitudes affect food choice? Appetite 149:104630. doi: 10.1016/j.appet.2020.104630

Barth, G., and Gaillard, C. (1997). Physiology and genetics of the dimorphic fungus Yarrowia lipolytica. FEMS Microbiol. Rev. 19, 219-237. doi: 10.1111/j.15746976.1997.tb00299.x

Bayitse, R., Hou, X., and Bjerre, A. (2015). Optimisation of enzymatic hydrolysis of cassava peel to produce fermentable sugars. AMB Expr 5:60. doi: 10.1186/ s13568-015-0146-z

Bednarski, W., Adamczak, M., Tomasik, J., and Plaszczyk, M. (2004). Application of oil refinery waste in the biosynthesis of glycolipids by yeast. Bioresour. Technol. 95, 15-18. doi: 10.1016/j.biortech.2004.01.009

BeMiller, J. N. (2019). "Gellans, curdlan, dextrans, levans, and pullulan," in Carbohydrate Chemistry for Food Scientists, ed. J. N. BeMiller (West Lafayette: Woodhead Publishing and AACC International Press), 271-278. doi: 10.1016/ b978-0-12-812069-9.00012-1

Ben Atitallah, I., Antonopoulou, G., Ntaikou, I., Alexandropoulou, M., Nasri, M., Mechichi, T., et al. (2019). On the evaluation of different saccharification schemes for enhanced bioethanol production from potato peels waste via a newly isolated yeast strain of Wickerhamomyces anomalus. Bioresour. Technol. 289:121614. doi: 10.1016/j.biortech.2019.121614 
Benabda, O., Kasmi, M., Kachouri, F., and Hamdi, M. (2018). Valorization of the powdered bread waste hydrolysate as growth medium for baker yeast. Food Bioproducts Process. 109, 1-8. doi: 10.1016/j.fbp.2018.02.007

Berger, L. R. R., Montenegro Stamford, T. C., de Oliveira, K. ÁR., de Miranda Pereira Pessoa, A., de Lima, M. A. B., Estevez Pintado, M. M., et al. (2018). Chitosan produced from Mucorales fungi using agroindustrial by-products and its efficacy to inhibit Colletotrichum species. Int. J. Biol. Macromol. 108, 635-641. doi: 10.1016/j.ijbiomac.2017.11.178

Berntssen, M. H. G., Sundal, T. K., Olsvik, P. A., Amlund, H., Rasinger, J. D., Sele, V., et al. (2017). Sensitivity and toxic mode of action of dietary organic and inorganic selenium in Atlantic salmon (Salmon salar). Aquat. Toxicol. 192, 116-126. doi: 10.1016/j.aquatox.2017.09.014

Bezerra, K. G. O., Gomes, U. V. R., and Silva, R. O. (2019). The potential application of biosurfactant produced by Pseudomonas aeruginosa TGC01 using crude glycerol on the enzymatic hydrolysis of lignocellulosic material. Biodegradation 30, 351-361. doi: 10.1007/s10532-019-09883-w

Bhardwaj, G., Cameotra, S. S., and Chopra, H. K. (2013). Utilization of oleochemical industry by-products for biosurfactant production. AMB Express. 3:68. doi: 10.1186/2191-0855-3-68

Bhosale, P. B., and Gadre, R. V. (2001). Production of? $\beta$-carotene by a mutant of Rhodotorula glutinis. Appl. Microbiol. Biotechnol. 55, 423-427. doi: 10.1007/ s002530000570

Bussemaker, M. J., and Zhang, D. (2013). Effect of ultrasound on lignocellulosic biomass as a pretreatment for biorefinery and biofuel applications. Ind. Eng. Chem. Res. 52, 3563-3580. doi: 10.1021/ie3022785

Bustos, G., Moldes, A. B., Cruz, J. M., and Domínguez, J. M. (2005). Influence of metabolism pathway on lactic acid production from hemicellulosic trimming vine shoots hydrolysates using Lactobacillus pentosus. Biotechnol. Prog. 21, 793-798. doi: 10.1021/bp049603v

Camargo, D., Sydney, E. B., Leonel, L. V., Pintro, T. C., and Sene, L. (2019). Dilute acid hydrolysis of sweet sorghum bagasse and fermentability of the hemicellulosic hydrolysate. Braz. J. Chem. Eng. 36, 143-156. doi: 10.1590/01046632.20190361s20170643

Cameotra, S. S., and Makkar, R. S. (1998). Synthesis of biosurfactants in extreme conditions. Appl. Microbiol. Biotechnol. 50, 520-529. doi: 10.1007/ s002530051329

Campañone, L. A., Paola, C. A., and Mascheroni, R. H. (2012). Modeling and simulation of microwave heating of foods under different process schedules. Food Bioprocess Tech. 5, 738-749. doi: 10.1007/s11947-010-0378-5

Capelli, B., Bagchi, D., and Cysewski, G. R. (2013). Synthetic astaxanthin is significantly inferior to algal-based astaxanthin as an antioxidant and may not be suitable as a human nutraceutical supplement. Nutrafoods 12, 145-152. doi: 10.1007/s13749-013-0051-5

Cardoso, L. A. C., Jäckel, S., Karp, S. G., Framboisier, X., Chevalot, I., and Marc, I. (2016). Improvement of Sporobolomyces ruberrimus carotenoids production by the use of raw glycerol. Bioresour. Technol. 200, 374-379. doi: 10.1016/j. biortech.2015.09.108

Carvalheiro, F., Duarte, L. C., and Gírio, F. M. (2008). Hemicellulose biorefineries: a review on biomass pretreatments. J. Sci. Ind. Res. 67, 849-864.

Chaleomrum, N., Chookietwattana, K., and Dararat, S. (2014). Production of PHA from cassava starch wastewater in sequencing batch reactor treatment system. APCBEE Proc. 8, 167-172. doi: 10.1016/j.apcbee.2014.03.021

Chandel, A. K., Antunes, F. A. F., Silva, M. B., and Silva, S. S. (2013). Unraveling the structure of sugarcane bagasse after soaking in concentrated aqueous ammonia (SCAA) and ethanol production by Scheffersomyces (Pichia) stipitis. Biotechnol. Biofuels 6:102. doi: 10.1186/1754-68 34-6-102

Chandel, A. K., Garlapati, V. K., Singh, A. K., Antunes, F. A. F., and da Silva, S. S. (2018). The path forward for lignocellulose biorefineries: bottlenecks, solutions, and perspective on commercialization. Bioresour. Technol. 264, 370-381. doi: 10.1016/j.biortech.2018.06.004

Chaturvedi, S., Bhattacharya, A., Nain, L., Prasanna, R., and Khare, S. K. (2019). Valorization of agro-starchy wastes as substrates for oleaginous microbes. Biomass Bioenerg. 127:105294. doi: 10.1016/j.biombioe.2019.105294

Chen, C., Junzhang, L., Weidong, W., He, H., Li, S. (2019). Cost-effective production of Surfactin from xylose-rich corncob Hydrolysate using Bacillus subtilis BS-37. Waste Biomass Valori. 10, 341-347. doi: 10.1007/s12649-017$0052-5$
Chen, Y., Guo, J., Li, F., Liu, M., Zhang, X., Guo, X., et al. (2014). Production of pullulan from xylose and hemicellulose hydrolysate by Aureobasidium pullulans AY82 with $\mathrm{pH}$ control and DL-dithiothreitol addition. Biotechnol. Bioproc. E. 19, 282-288. doi: 10.1007/s12257-013-0715-4

Choi, M. H., and Park, Y. H. (2003). Production of yeast biomass using waste Chinese cabbage. Biomass Bioenergy 25, 221-226. doi: 10.1016/S0961-9534(02) 0019

Christophe, G., Kumar, V., Nouaille, R., Gaudet, G., Fontanille, P., Pandey, A., et al. (2012). Recent developments in microbial oils production: a possible alternative to vegetable oils for biodiesel without competition with human food? Braz. Arch. Biol. Technol. 55, 29-46. doi: 10.1590/s1516-8913201200010 0004

Cipolatti, E. P., Remedi, R. D., Sá, C., dos, S., Rodrigues, A. B., Gonçalves Ramos, J. M., et al. (2019). Use of agroindustrial byproducts as substrate for production of carotenoids with antioxidant potential by wild yeasts. Biocatal. Agric. Biotechnol. 20:101208. doi: 10.1016/j.bcab.2019.101208

Coimbra, C. D., Rufino, R. D., Luna, J. M., and Sarubbo, L. A. (2009). Studies of the cell surface properties of Candida species and relation to the production of biosurfactants for environmental applications. Curr.Microbiol. 58, 245-251. doi: 10.1007/s00284-008-9315-5

Colet, R., Di Luccio, M., and Valduga, E. (2015). Fed-batch production of carotenoids by Sporidiobolus salmonicolor (CBS 2636): kinetic and stoichiometric parameters. Eur. Food Res. Technol. 240, 173-182. doi: 10.1007/ s00217-014-2318-5

Colet, R., Urnau, L., Bampi, J., Zeni, J., Dias, B. B., Rodrigues, E., et al. (2017). Use of low-cost agro products as substrate in semi-continuous process to obtain carotenoids by Sporidiobolus salmonicolor. Biocatal. Agric. Biotechnol. 11, 268-274. doi: 10.1016/j.bcab.2017.07.015

Confente, I., Scarpi, D., and Russo, I. (2019). Marketing a new generation of bio-plastics products for a circular economy: the role of green self-identity, selfcongruity, and perceived value. J. Bus. Res. 112, 431-439. doi: 10.1016/j.jbusres. 2019.10.030

Cunha, M. A. A., Turmina, J. A., Ivanov, R. C., Barroso, R. R., Marques, P. T., Fonseca, E. A., et al. (2012). Lasiodiplodan, an exocellular $(1 \rightarrow 6)-\beta$-d-glucan from Lasiodiplodia theobromae MMPI: production on glucose, fermentation kinetics, rheology and anti-proliferative activity. J. Ind. Microbiol. Biot. 39, 1179-1188. doi: 10.1007/s10295-012-1112-2

Daverey, A., and Pakshirajan, K. (2009). Production, characterization, and properties of sophorolipids from the yeast Candida bombicola using a lowcost fermentative medium. Appl. Biochem. Biotech. 158, 663-674. doi: 10.1007/ s12010-008-8449-z

Demirci, A., and Pometto, A. L. (2000). Enhanced organically bound chromium yeast production. J. Agr. Food. Chem. 48, 531-536. doi: 10.1021/jf990771q

Deshpande, M., and Daniels, L. (1995). Evaluation of sophorolipid biosurfactant production by Candida bombicola using animal fat. Bioresour. Technol. 54, 143-150. doi: 10.1016/0960-8524(95)00116-6

Dhamodharan, K., Ahlawat, S., Kaushal, M., and Rajendran, K. (2020). "Economics and cost analysis of waste biorefineries," in Refining Biomass Residues for Sustainable Energy and Bioproducts: Technology, Advances, Life Cycle Assessment and Economics, eds R. P. Kumar, E. Gnansounou, J. K. Raman, and G. Baskar (Massachusetts: Academic Press), 545-565. doi: 10.1016/b978-0-12818996-2.00025-9

Dietrich, K., Dumont, M.-J., Del Rio, L. F., and Orsat, V. (2018). Sustainable PHA production in integrated lignocellulose biorefineries. New Biotechnol. 49, 161-168. doi: 10.1016/j.nbt.2018.11.004

Donot, F., Fontana, A., Baccou, J. C., Strub, C., and Schorr-Galindo, S. (2014). Single cell oils (SCOs) from oleaginous yeasts and moulds: production and genetics. Biomass Bioenerg. 68, 135-150. doi: 10.1016/j.biombioe.2014.06.016

Dursun, D., and Dalgıı̧, A. C. (2016). Optimization of astaxanthin pigment bioprocessing by four different yeast species using wheat wastes. Biocatal. Agric. Biotechnol. 7, 1-6. doi: 10.1016/j.bcab.2016.04.006

Dursun, D., Dalgiç, A. C., and Co, A. (2016). Biocatalysis and Agricultural Biotechnology Optimization of astaxanthin pigment bioprocessing by four different yeast species using wheat wastes. Biocatal. Agric. Biotechnol. 7, 1-6. doi: 10.1016/j.bcab.2016.04.006

El-Banna, A. A., El-Razek, A. M. A., and El-Mahdy, A. R. (2012). Some Factors Affecting the Production of Carotenoids by Rhodotorula glutinis var. glutinis. Food Nutr. Sci. 03, 64-71. doi: 10.4236/fns.2012.31011 
Emamverdi, M., Zare-Shahneh, A., Zhandi, M., Zaghari, M., Minai-Tehrani, D., and Khodaei-Motlagh, M. (2018). An improvement in productive and reproductive performance of aged broiler breeder hens by dietary supplementation of organic selenium. Theriogenology 126, 279-285. doi: 10. 1016/j.theriogenology.2018.12.001

Embaby Id, A. M., Hussein, M. N., and Hussein, A. (2018). Monascus orange and red pigments production by Monascus purpureus ATCC16436 through co-solid state fermentation of corn cob and glycerol: an eco-friendly environmental low cost approach. PLoS One 13:e207755. doi: 10.1371/journal.pone.0207755

Esmaeili, S., Khosravi-Darani, K., Pourahmad, R., and Komeili, R. (2012). An experimental design for production of selenium-enriched yeast. World Appl. Sci. J. 19, 31-37. doi: 10.5829/idosi.wasj.2012.19.01.2634

Falk, M., Lebed, P., Bernhoft, A., Framstad, T., Kristoffersen, A. B., Salbu, B., et al. (2019). Effects of sodium selenite and L-selenomethionine on feed intake, clinically relevant blood parameters and selenium species in plasma, colostrum and milk from high-yielding sows. J. Trace Elem. Med. Biol. 52, 176-185. doi: 10.1016/j.jtemb.2018.12.009

FDA (2019). Generally Recognized as Safe (GRAS). Paris: FDA.

Fenibo, E. O., Ijoma, G. N., Selvarajan, R., and Chikere, C. B. (2019). Microbial surfactants: the next generation multifunctional biomolecules for applications in the petroleum industry and its associated environmental remediation. Microorganisms 7:581. doi: 10.3390/microorganisms7110581

Fernando, S., Adhikari, S., Chandrapal, C., and Murali, N. (2006). Biorefineries:? Current status, challenges, and future direction. Energ. Fuel. 20, 1727-1737.

Ferreira, J. A., Mahboubi, A., Lennartsson, P. R., and Taherzadeh, M. J. (2016). Waste biorefineries using filamentous ascomycetes fungi: present status and future prospects. Bioresour. Technol. 215, 334-345. doi: 10.1016/j.biortech.2016. 03.018

Fontes, G. C., Amaral, P. F. F., and Coelho, M. A. Z. (2008). Produção de biossurfactante por levedura. Química Nova 31, doi: 10.1590/S010040422008000800033

Franco-Marcelino, P. R., da Silva, V. L., Rodrigues Philippini, R., Von Zuben, C. J., Contiero, J., dos Santos, J. C., et al. (2017). Biosurfactants produced by Scheffersomyces stipitis cultured in sugarcane bagasse hydrolysate as new green larvicides for the control of Aedes aegypti, a vector of neglected tropical diseases. PLoS One 12:e0187125. doi: 10.1371/journal.pone.0187125

Freitas, C., Parreira, T. M., Roseiro, J., Reis, A., and Da Silva, T. L. (2014). Selecting low-cost carbon sources for carotenoid and lipid production by the pink yeast Rhodosporidium toruloides NCYC 921 using flow cytometry. Bioresour. Technol. 158, 355-359. doi: 10.1016/j.biortech.2014.02.071

Fu, D., and Mazza, G. (2011). Aqueous ionic liquid pretreatment of straw. Bioresour. Technol. 102, 7008-7011. doi: 10.1016/j.biortech.2011.04.049

Gaboardi, G., Santos, D. G., Mendes, L., Centeno, L., Meireles, T., Vargas, S., et al. (2018). Bioremediation and biomass production from the cultivation of probiotic Saccharomyces boulardii in parboiled rice effluent. J. Environ. Manag. 226, 180-186. doi: 10.1016/j.jenvman.2018.08.027

Gaensly, F., Wille, G. M. F. C., Brand, D., and Bonfim, T. M. B. (2011). Iron enriched Saccharomyces cerevisiae maintains its fermenting power and bakery properties. Ciencia Tecnol Alime. 31, 980-983.

Gao, W., Hagver, R., Shah, V., Xie, W., Gross, R. A., Ilker, M. F., et al. (2007). Glycolipid polymer synthesized from natural lactonic sophorolipids by ringopening metathesis polymerization. Macromolecules 40, 145-147. doi: 10.1021/ ma0620159

Goswami, G., Chaudhuri, S., and Dutta, D. (2015). Studies on the stability of a carotenoid produced by a novel isolate using low cost agro-industrial residue and its application in different model systems. LWT - Food Sci. Technol. 63, 780-790. doi: 10.1016/j.lwt.2015.03.017

Graham, H., Santos, T. T., and Wadt, G. (2009). Modo de ação de Produtos à Base de Leveduras na Nutrição Animal. Available online at: https://www.avisite.com. br/cet/img/20091105_leveduras.pdf (accessed July 8, 2020).

Grand View Research (2017). Beta-glucan Market Analysis. Maharashtra: Grand View Research.

Grand View Research (2018). Protein Extracts from Single Cell Protein and Other Conventional Sources Market Report. Maharashtra: Grand View Research.

Gusmão, C., Rufino, R., and Sarubbo, L. (2010). Laboratory production and characterization of a new biosurfactant from Candida glabrata UCP1002 cultivated in vegetable fat waste applied to the removal of hydrophobic contaminant. World J. Microb. Biot. 26, 1683-1692.
Hamano, P. S., and Kilikian, B. V. (2006). Production of red pigments by Monascus ruber in culture media containing corn steep liquor. Brazilian J. Chem. Eng. 23, 443-449. doi: 10.1590/S0104-66322006000400002

Hassan, S. S., Williams, G. A., and Jaiswal, A. K. (2018). Emerging technologies for the pretreatment of lignocellulosic biomass. Bioresour. Technol. 262, 310-318. doi: 10.1016/j.biortech.2018.04.099

Hernández-Almanza, A., Montañez-Sáenz, J., Martínez-Ávila, C., RodríguezHerrera, R., and Aguilar, C. N. (2014). Carotenoid production by Rhodotorula glutinis YB-252 in solid-state fermentation. Food Biosci. 7, 31-36. doi: 10.1016/ j.fbio.2014.04.001

Hu, Z., Que, Y., Gao, Y., Yin, Y., and Zhao, Y. (2015). Using black liquor from the soda pulping process for protein production by Candida utilis. Bioresources 10, 3908-3921.

Industry ARC (2018). Biopolymers Market - Forecast (2020 - 2025). Available online at: https://www.industryarc.com/Report/11739/biopolymers-market.html (accessed July 8, 2020).

Ingle, A. P., Philippini, R. R., and da Silva, S. S. (2020a). Pretreatment of sugarcane bagasse using two different acid-functionalized magnetic nanoparticles: a novel approach for high sugar recovery. Renew. Energy 150, 957-964. doi: 10.1016/j. renene.2019.11.146

Ingle, A. P., Philippini, R. R., de Souza Melo, Y. C., and da Silva, S. S. (2020b). Acidfunctionalized magnetic nanocatalysts mediated pretreatment of sugarcane straw: an eco-friendly and cost-effective approach. Cellulose doi: 10.1007/ s10570-020-03262-y

Isono, K., Uramoto, M., Kusakabe, H., Kimura, K. I., Izaki, K., Nelson, C. C., et al. (1985). Liposidomycins: novel nucleoside antibiotics which inhibit bacterial peptidoglycan synthesis. J. Antibiot. 38, 1617-1621.

Jin, M., Slininger, P. J., Dien, B. S., Waghmode, S., Moser, B. R., Orjuela, A., et al. (2015). Microbial lipid-based lignocellulosic biorefinery: feasibility and challenges. Trends Biotechnol. 33, 43-54. doi: 10.1016/j.tibtech.2014. 11.005

Jurado, M., Martinèz, T., Martinez, M. J., and Saparrat, M. C. N. (2011). Application of white-rot fungi in transformation, detoxification, or revalorization of agriculture wastes: role of laccase in the processes. Comprehensive Biotechnol. 6, 595-603. doi: 10.1016/B978-0-08-088504-9. 00398-6

Juszczyk, P., Rymowicz, W., Kita, A., and Rywiñska, A. (2019). Biomass production by Yarrowia lipolytica yeast using waste derived from the production of ethyl esters of polyunsaturated fatty acids of flaxseed oil. Ind. Crops Prod. 138:111590. doi: 10.1016/j.indcrop. 2019.111590

Kagimura, F. Y., da Cunha, M. A. A., Theis, T. V., Malfatti, C. R. M., Dekker, R. F. H., Barbosa, A. M., et al. (2015). Carboxymethylation of $(1 \rightarrow 6)-\beta$-glucan (lasiodiplodan): preparation, characterization and antioxidant evaluation. Carbohydr. Polym. 127, 390-399.

Kantifedaki, A., Kachrimanidou, V., Mallouchos, A., Papanikolaou, S., and Koutinas, A. A. (2018). Orange processing waste valorization for the production of bio-based pigments using the fungal strains Monascus purpureus and Penicillium purpurogenum. J. Clean. Prod. 185, 882-890. doi: 10.1016/j.jclepro. 2018.03.032

Khawla, B. J., Sameh, M., Imen, G., Donyes, F., Dhouha, G., Raoudha, E. G., et al. (2014). Potato peel as feedstock for bioethanol production: a comparison of acidic and enzymatic hydrolysis. Ind. Crop Prod. 52, 144-149. doi: 10.1016/j. indcrop.2013.10.025

Kieliszek, M., Kot, A. M., Bzducha-Wróbel, A., Błazejak, S., Gientka, I., and Kurcz, A. (2017). Biotechnological use of Candida yeasts in the food industry: a review. BMS 3I, 185-198. doi: 10.1016/j.fbr.2017. 06.001

Kim, I., Lee, I., Jeon, S. H., Hwang, T., and Han, J.-I. (2015). Hydrodynamic cavitation as a novel pretreatment approach for bioethanol production from reed. Bioresour. Technol. 192, 335-339.

Kot, A. M., Błażejak, S., Kieliszek, M., Gientka, I., Piwowarek, K., and Brzeziñska, R. (2020). Production of lipids and carotenoids by Rhodotorula gracilis ATCC 10788 yeast in a bioreactor using low-cost wastes. Biocatal. Agric. Biotechnol. 26:101634. doi: 10.1016/j.bcab.2020.101634

Kumar, A., Janardhan, A., Viswanath, B., Monika, K., Jung, J., and Narasimha, G. (2016). Evaluation of orange peel for biosurfactant production by Bacillus licheniformis and their ability to degrade naphthalene and crude oil. 3 Biotech. 6:43. doi: 10.1007/s13205-015-0362-x 
Kumar, A. K., and Sharma, S. (2017). Recent updates on different methods of pretreatment of lignocellulosic feedstocks: a review. Bioresour. Bioprocess 4:7. doi: 10.1186/s40643-017-0137-9

Kumar, P., Barrett, D. M., Delwiche, M. J., and Stroeve, P. (2009). Methods for pretreatment of lignocellulosic biomass for efficient hydrolysis and biofuel production. Ind. Eng. Chem. Res. 48, 3713-3729.

Kumar, P. S., and Yaashikaa, P. R. (2020). "Sources and operations of waste biorefineries," in Refining Biomass Residues for Sustainable Energy and Bioproducts: Technology, Advances, Life Cycle Assessment and Economics, eds R. P. Kumar, E. Gnansounou, J. K. Raman, and G. Baskar (Massachusetts: Academic Press), 111-133.

Lamsal, B., Yoo, J., Brijwani, K., and Alavi, S. (2010). Extrusion as a thermomechanical pre-treatment for lignocellulosic ethanol. Biomass Bioenerg. 34, 1703-1710.

Lee, J.-E., Vadlani, P. V., and Faubion, J. (2017). Corn bran bioprocessing: development of an integrated process for microbial lipids production. Bioresour. Technol. 243, 196-203. doi: 10.1016/j.biortech.2017. 06.065

Li, M., and Wilkins, M. R. (2020). Recent advances in polyhydroxyalkanoate production: feedstocks, strains and process developments. Int. J. Biol. Macromol. 156, 691-703. doi: 10.1016/j.ijbiomac.2020.04.082

Li, X., Ouyang, J., Xu, Y., Chen, M., Song, X., Yong, Q., et al. (2009). Optimization of culture conditions for production of yeast biomass using bamboo wastewater by response surface methodology. Bioresour. Technol. 100, 3613-3617. doi: 10.1016/j.biortech.2009.03.001

Lin, C., Jia, X., Fang, Y., Chen, L., Zhang, H., Lin, R., et al. (2019). Enhanced production of prodigiosin by Serratia marcescens FZSF02 in the form of pigment pellets. Electron. J. Biotechnol. 40, 58-64. doi: 10.1016/j.ejbt.2019.04. 007

Lin, Y. L., Wang, T. H., Lee, M. H., and Su, N. W. (2008). Biologically active components and nutraceuticals in the Monascus-fermented rice: a review. Appl. Microbiol. Biotechnol. 77, 965-973. doi: 10.1007/s00253-007-1256-6

Liu, F., and Zhu, M. (2017). Investigation on the production of carotenoid from molasses by Phaffia rhodozyma. Int. J. Mod. Biol. Med. 8, 1-13.

Liu, K., Sun, Y., Cao, M., Wang, J., Lu, J. R., and Xu, H. (2019). Rational design, properties and applications of biosurfactants: a short review of recent advances. Curr. Opin. Colloid Interface Sci. 45, 57-67.

Liu, Y., Koh, C. M. J., and Ji, L. (2011). Bioconversion of crude glycerol to glycolipids in Ustilago maydis. Bioresour. Technol. 102, 3927-3933.

Liu, Z., Feist, A. M., Dragone, G., and Mussatto, S. I. (2020). Lipid and carotenoid production from wheat straw hydrolysates by different oleaginous yeasts. J. Clean. Prod. 249:119308. doi: 10.1016/j.jclepro.2019.119308

Lopes, F. C., Tichota, D. M., Pereira, J. Q., Segalin, J., De Oliveira Rios, A., and Brandelli, A. (2013). Pigment production by filamentous fungi on agroindustrial byproducts: an eco-friendly alternative. Appl. Biochem. Biotechnol. 171, 616-625. doi: 10.1007/s12010-013-0392-y

Lopes, M., Gomes, A. S., Silva, C. M., and Belo, I. (2018). Microbial lipids and added value metabolites production by Yarrowia lipolytica from pork lard. J. Biotechnol. 265, 76-85. doi: 10.1016/j.jbiotec.2017.11.007

Louhasakul, Y., Cheirsilp, B., Maneerat, S., and Prasertsan, P. (2018). Potential use of flocculating oleaginous yeasts for bioconversion of industrial wastes into biodiesel feedstocks. Renew. Energy 136, 1311-1319.

Madani, M., Enshaeieh, M., and Abdoli, A. (2017). Single cell oil and its application for biodiesel production. Process Saf. Environ. 111, 747-756. doi: 10.1016/j.psep. 2017.08.027

Magalhães, C. E. B., Souza-Neto, M. S., Astolfi-Filho, S., and Matos, T. S. R. (2018). Candida tropicalis able to produce yeast single cell protein using sugarcane bagasse hemicellulosic hydrolysate as carbon source. Biotech. Res. Innovat. 2, 19-21. doi: 10.1016/j.biori.2018.08.002

Mahapatra, S., and Banerjee, D. (2013). Fungal exopolysaccharide: production, composition and applications. Microbiol. Insights 6, 1-16.

Makkar, R. S., Cameotra, S. S., and Banat, I. M. (2011). Advances in utilization of renewable substrates for biosurfactant production. AMB Express 1:5. doi: 10.1186/2191-0855-1-5

Marcelino, P. R. F., Peres, G. F. D., Terán-Hilares, R., Pagnocca, F. C., Rosa, C. A., Lacerda, T. M., et al. (2019). Biosurfactants production by yeasts using sugarcane bagasse hemicellulosic hydrolysate as new sustainable alternative for lignocellulosic biorefineries. Ind. Crops Prod. 129, 212-223.
Martinez-Silveira, A., Villarreal, R., Garmendia, G., Rufo, C., and Vero, S. (2019). Process conditions for a rapid in situ transesterification for biodiesel production from oleaginous yeasts. Electron. J. Biotechn. 38, 1-9. doi: 10.1016/j.ejbt.2018.11. 006

Martiniano, S. E., Philippini, R. R., Chandel, A. K., Rosa, C. A., Pagnocca, F. C., and da Silva, S. S. (2014). Evaluation of rice bran extract as a nitrogen source for improved hemicellulosic ethanol production from sugarcane bagasse by new xylose-fermenting yeast strains isolated from brazilian forests. Sugar Tech. 16, 1-8. doi: 10.1007/s12355-013-0219-8

Martiniano, S. E., Philippini, R. R., and Silva, S. S. (2016). Processo de produção de leveduras enriquecidas com selênio a partir de resíduos vegetais. BR. Patent No 102016 0249023: BR. Agência: USP de Inovação.

Mata-Gómez, L., Montañez, J., Méndez-Zavala, A., and Aguilar, C. (2014). Biotechnological production of carotenoids by yeasts: an overview. Microb. Cell Fact. 13:12. doi: 10.1186/1475-2859-13-12

Moldes, A. B., Torrado, A., Converti, A., and Domínguez, J. M. (2006). Complete bioconversion of hemicellulosic sugars from agricultural residues into lactic acid by Lactobacillus pentosus. Appl. Biochem. Biotechnol. 135, 219-227.

Moncada, B. J., Aristizábal, V. M., Cardona, C. A. A. (2016). Design strategies for sustainable biorefineries. Biochem. Eng. J. 116, 122-134. doi: 10.1016/j.bej.2016. 06.009

Montanti, J., Nghiem, N. P., Johnston, D. B., Montanti, J., Nghiem, N. P., and Johnston, D. B. (2011). Production of astaxanthin from cellulosic biomass sugars by mutants of the yeast Phaffia rhodozyma. Appl. Biochem. Biotechnol. 164, 655-665. doi: 10.1007/s12010-011-9165-7

Monteiro, A., Domingues, V. S., and Souza, M. V. (2012). Bioconversion of biodiesel refinery waste in the bioemulsifier by Trichosporon mycotoxinivorans CLA2. Biotechnol. Biofuels. 5:29. doi: 10.1186/1754-6834-5-29

Monteiro, A. S., Coutinho, J., Júnior, A. C., Rosa, C. A., Siqueira, E. P., and Santos, V. L. (2009). Characterization of new biosurfactant produced by Trichosporon montevideense CLOA 72 isolated from dairy industry effluents. J. Basic Microbiol. 49, 1-11.

Mood, S. H., Golfeshan, A. H., Tabatabaei, M., Jouzani, G. S., Najafi, G. H., Gholami, M., et al. (2013). Lignocellulosic biomass to bioethanol, a comprehensive review with a focus on pretreatment. Renew. Sust. Energ. Rev. 27, 77-93. doi: 10.1016/j.rser.2013.06.033

Mordor Intelligence (2019). Biopolymer Packaging Market - Growth, Trends, and Forecast (2020 - 2025). Hyderabad: Mordor Intelligence.

Moreira, M. D., Melo, M. M., Coimbra, J. M., Reis, K. C., Schwan, R. F., and Silva, C. F. (2018). Solid coffee waste as alternative to produce carotenoids with antioxidant and antimicrobial activities. Waste Manag. 82, 93-99. doi: 10.1016/j.wasman.2018.10.017

Morita, T., Konishi, M., Fukuoka, T., Imura, T., and Kitamoto, D. (2007). Microbial conversion of glycerol into glycolipid biosurfactants, mannosylerythritol lipids, by a basidiomycete yeast, Pseudozyma antarctica JCM 10317T. J. Biosci. Bioeng. 104, 78-81.

Mugwagwa, L. R., and Chimphango, A. F. A. (2020). Optimising wheat straw alkali-organosolv pre-treatment to enhance hemicellulose modification and compatibility with reinforcing fillers. Int. J. Biol. Macromol. 143, 862-872. doi: 10.1016/j.ijbiomac.2019.09.147

Murphy, E. J., Masterson, C., Rezoagli, E., O’Toole, D., Major, I., Stack, G. D., et al. (2020). $\beta$-Glucan extracts from the same edible shiitake mushroom Lentinus edodes produce differential in-vitro immunomodulatory and pulmonary cytoprotective effects - Implications for coronavirus disease (COVID-19) immunotherapies. Sci. Total Environ. 732:139330. doi: 10.1016/j.scitotenv.2020. 139330

Murthy, K. N. C., Vanitha, A., Rajesha, J., Swamy, M. M., Sowmya, P. R., and Ravishankar, G. A. (2005). In vivo antioxidant activity of carotenoids from Dunaliella salina - A green microalga. Life Sci. 76, 1381-1390. doi: 10.1016/j. Ifs. 2004.10.015

Nair, A. S., Al-Bahry, S., and Sivakumar, N. (2020). Co-production of microbial lipids and biosurfactant from waste office paper hydrolysate using a novel strain Bacillus velezensis ASN1. Biomass Conv. Bioref. 10, 383-391. doi: 10.1007/ s13399-019-00420-6

Nair, A. S., Al-Battashi, H., Al-Akzawi, A., Annamalai, N., Gujarathi, A., AlBahry, S., et al. (2018). Waste office paper: a potential feedstock for cellulase production by a novel strain Bacillus velezensis ASN1. Waste Manag. 79, 491-500. 
Nakashima, K., Ebi, Y., Shibasaki-Kitakawa, N., Soyama, H., and Yonemoto, T. (2016). Hydrodynamic cavitation reactor for efficient pretreatment of lignocellulosic biomass. Ind. Eng. Chem. Res. 55, 1866-1871. doi: 10.1021/acs. iecr.5b04375

Nasseri, A. T., Rasaoul-Amini, S., Morowvat, M. H., and Ghasemi, Y. (2011). Single cell protein: production and process. Am. J. Food Technol. 6, 103-116. doi: 10.3923/ajft.2011.103.116

National Research Council (2011). "Barriers to achieving RFS2," in Renewable Fuel Standard: Potential Economic and Environmental Effects of U.S. Biofuel Policy. (Washington, DC: The National Academies Press), 263-286.

Naughton, P. J., Marchant, R., Naughton, V., and Banat, I. M. (2019). Microbial biosurfactants: current trends and applications in agricultural and biomedical industries. J. Appl. Microbiol. 127, 12-28.

Nimnoi, P., and Lumyong, S. (2011). Improving solid-state fermentation of Monascus purpureus on agricultural products for pigment production. Food Bioprocess. Technol. 4, 1384-1390. doi: 10.1007/s11947-009-0233-8

Özüdoğru, H. M. R., Nieder-Heitmann, M., Haigh, K. F., and Görgens, J. F. (2019). Techno-economic analysis of product biorefineries utilizing sugarcane lignocelluloses: Xylitol, citric acid and glutamic acid scenarios annexed to sugar mills with electricity co-production. Ind. Crop Prod. 133, 259-268. doi: 10.1016/ j.indcrop.2019.03.015

P\&S Intelligence (2018). Protein Extracts from Single Cell Protein Sources Market Overview. Delhi: Prescient \& Strategic Intelligence.

Panesar, R., Kaur, S., and Panesar, P. S. (2015). Production of microbial pigments utilizing agro-industrial waste: a review. Curr. Opin. Food Sci. 1, 70-76. doi: 10.1016/j.cofs.2014.12.002

Papanikolaou, S., and Aggelis, G. (2011). Lipids of oleaginous yeasts. Part II: technology and potential applications. Eur. J. Lipid Sci. Technol. 113, 10521073. doi: 10.1002/ejlt.201100015

Parsons, S., Allen, M. J., and Chuck, C. J. (2020). Coproducts of algae and yeastderived single cell oils: a critical review of their role in improving biorefinery sustainability. Bioresour. Technol. 303:122862. doi: 10.1016/j.biortech.2020. 122862

Patakova, P. (2013). Monascus secondary metabolites: production and biological activity. J. Ind. Microbiol. Biotechnol. 40, 169-181. doi: 10.1007/s10295-0121216-8

Paye, J. M. D., Guseva, A., Hammer, S. K., Gjersing, E., Davis, M. F., Davison, B. H., et al. (2016). Biological lignocellulose solubilization: comparative evaluation of biocatalysts and enhancement via co-treatment. Biotechnol. Biofuels 9:8. doi: 10.1186/s13068-015-0412-y

Pekin, G., and Vardar-Sukan, F. N. K. (2005). Production of sophorolipids from Candida bombicola ATCC 22214 using turkish corn oil and honey. Eng. Sci. Life. 5, 357-362.

Petrik, S., Obruèa, S., Benešová, P., and Márová, I. (2014). Bioconversion of spent coffee grounds into carotenoids and other valuable metabolites by selected red yeast strains. Biochem. Eng. J. 90, 307-315. doi: 10.1016/j.bej.2014.06.025

Philippini, R. R., Martiniano, S. E., Marcelino, P. R. F., Santos, J. C., and Silva, S. S. (2018). "Corn-bran hydrolysate as low-cost media for lasiodiplodan biopolymer by filamentous fungi Lasiodiplodia theobromae," in Exploring Microorganisms: Recent Advances in Applied Microbiology, ed. A. Méndez-Vilas (Irvine: Universal-Publishers), 134.

Philippini, R. R., Martiniano, S. E., Santos, J. C., da Silva, S. S., and Chandel, A. K. (2019). "Fermentative production of beta-glucan: properties and potential applications," in Bioprocessing for Biomolecules Production, eds G. Molina, V. Gupta, B. Singh, and N. Gathergood (New Jersey: John Wiley \& Sons), 303-320.

Pitt, F. D., Domingos, A. M., and Barros, A. A. C. (2019). Purification of residual glycerol recovered from biodiesel production. SAJCE 29, 42-51. doi: 10.1016/j. sajce.2019.06.001

Portilla-Rivera, O. M., Moldes, A. B., Torrado, A. M., and Domínguez, J. M. (2007). Lactic acid and biosurfactants production from hydrolyzed distilled grape marc. Process Biochem. 42, 1010-1020.

Probst, K. V., and Vadlani, P. V. (2015). Production of single cell oil from Lipomyces starkeyi ATCC 56304 using biorefinery by-products. Bioresour. Technol. 198, 268-275. doi: 10.1016/j.biortech.2015.09.018

Prückler, M., Siebenhandl-Ehn, S., Apprich, S., Höltinger, S., Haas, C., Schmid, E., et al. (2014). Wheat bran-based biorefinery 1: composition of wheat bran and strategies of functionalization. LWT Food Sci. Technol. 56, 211-221. doi: 10.1016/j.lwt.2013.12.004
Rai, M., Ingle, A. P., Pandit, R., Paralikar, P., and da Silva, S. S. (2019). Emerging role of nanobiocatalysts in hydrolysis of lignocellulosic biomass leading to sustainable bioethanol production. Catal. Rev. 61, 1-26.

Rao, M. P. N., Xiao, M., and Li, W. J. (2017). Fungal and bacterial pigments: secondary metabolites with wide applications. Front. Microbiol. 8:1113. doi: $10.3389 /$ fmicb.2017.01113

Regy, J., and Padmaja, G. (2013). Comparative studies on the production of glucose and high fructose syrup from tuber starches. Int. Res. J. Biol. Sci. 2, 68-75.

Resende, T. M., and da Costa, M. M. (2019). "Biopolymers of sugarcane," in Sugarcane Biorefinery, Technology and Perspectives, eds F. Santos, S. Rabelo, M. Matos, and P. Eichler (Massachusetts: Academic Press), 229-254. doi: 10.1016/ b978-0-12-814236-3.00012-3

Roadjanakamolson, M., and Suntornsuk, W. (2010). Production of $\beta$-caroteneenriched rice bran using solid-state fermentation of Rhodotorula glutinis. J. Microbiol. Biotechnol. 20, 525-531. doi: 10.4014/jmb.0809.0550

Rodrigues, T. V. D., Amore, T. D., Teixeira, E. C., Burkert, J. F., and de, M. (2019). Carotenoid production by Rhodotorula mucilaginosa in Batch and Fed-Batch fermentation using agroindustrial byproducts. Food Technol. Biotechnol. 57, 388-398. doi: 10.17113/ftb.57.03.19.6068

Roepcke, C. B. S., Vandenberghe, L. P. S., and Soccol, C. R. (2011). Optimized production of Pichia guilliermondii biomass with zinc accumulation by fermentation. Anim. Feed Sci. Technol. 163, 33-42. doi: 10.1016/j.anifeedsci. 2010.09.018

Roukas, T., and Kotzekidou, P. (2020). Rotary biofilm reactor: a new tool for long-term bioethanol production from non-sterilized beet molasses by Saccharomyces cerevisiae in repeated-batch fermentation. J. Clean. Prod. 257:120519.

Routray, W., Dave, D., Cheema, S. K., Ramakrishnan, V. V., and Pohling, J. (2019). Biorefinery approach and environment-friendly extraction for sustainable production of astaxanthin from marine wastes. Crit. Rev. Biotechnol. 39, 469488. doi: 10.1080/07388551.2019.1573798

Rufino, R., Sarubbo, L., and Campos-Takaki, G. (2007). Enhancement of stability of biosurfactant produced by Candida lipolytica using industrial residue as substrate. World J. Microb. Biot. 23, 729-734.

Rufino, R. D., Sarubbo, L. A., Neto, B. B., and Campos-Takaki, G. M. (2008). Experimental design for the production of tensoactive agent by Candida lipolytica. J. Ind. Microbiol. Biot. 35, 907-914.

Ruiz, H. A., Conrad, M., Sun, S.-N., Sanchez, A., Rocha, G. J. M., Romaní, A., et al. (2019). Engineering aspects of hydrothermal pretreatment: from batch to continuous operation, scale-up and pilot reactor under biorefinery concept. Bioresour. Technol. 229:122685. doi: 10.1016/j.biortech.2019.122685

Sagia, S., Sharma, A., Singh, S., Chaturvedi, S., Nain, P. K. S., and Nain, L. (2020). Single cell oil production by a novel yeast Trichosporon mycotoxinivorans for complete and ecofriendly valorization of paddy straw. Electron. J. Biotechn. 44, 60-68. doi: 10.1016/j.ejbt.2020.01.009

Sahu, O. (2018). Assessment of sugarcane industry: suitability for production, consumption, and utilization. Ann. Agrar. Sci. 16, 389-395. doi: 10.1016/j.aasci. 2018.08.001

Samad, A., Zhang, J., Chen, D., and Liang, Y. (2014). Sophorolipid production from biomass hydrolysates. Appl. Biochem. Biotechnol. 175, 2246-2257.

Samadi, M., Samadi, S., and Darzi, G. N. (2016). Production of single cell protein from sugarcane bagasse by Saccharomyces cerevisiae in tray bioreactor. Int. J. Eng. 29, 1029-1036. doi: 10.5829/idosi.ije.2016.29. $08 \mathrm{~b} .01$

Sánchez-Martínez, M., Silva, E. G. P., Pérez-Corona, T., Cámara, C., Ferreira, S. L. C., and Madrid, Y. (2012). Selenite biotransformation during brewing. Evaluation by HPLC-ICP-MS. Talanta 88, 272-276. doi: 10.1016/j.talanta.2011. 10.041

Santori, G., Nicola, G. D., Moglie, M., and Polonara, F. (2012). A review analyzing the industrial biodiesel production practice starting from vegetable oil refining. Appl. Energy 92, 109-132.

Santos, D. K., Rufino, R. D., Luna, J. M., Santos, V. A., and Sarubbo, L. A. (2016). Biosurfactants: multifunctional Biomolecules of the 21st Century. Int. J. Mol. Sci. 17:401.

Santos, M. V., Faria, N. T., Fonseca, C., and Ferreira, F. C. (2018). Production of mannosylerythritol lipids from lignocellulose hydrolysates: tolerance thresholds of Moesziomyces antarcticus to inhibitors. J. Chem. Technol. Biotechnol. 94, 1064-1072. 
Santos-Ribeiro, J. E., da Silva Sant'Ana, A. M., Martini, M., Sorce, C., Andreucci, A., Nóbrega, D. J., et al. (2019). Rhodotorula glutinis cultivation on cassava wastewater for carotenoids and fatty acids generation. Biocatal. Agric. Biotechnol. 22:101419. doi: 10.1016/j.bcab.2019.101419

Sarker, T. C., Azam, S. M. G. G., and Bonanomi, G. (2017). Recent advances in sugarcane industry solid by-products valorization. Waste Biomass Valor. 8, 241-266. doi: 10.1007/s12649-016-9665-3

Schneider, T., Graeff-Hönninger, S., French, W. T., Hernandez, R., Merkt, N., Claupein, W., et al. (2013). Lipid and carotenoid production by oleaginous red yeast Rhodotorula glutinis cultivated on brewery effluents. Energy 61, 34-43. doi: 10.1016/j.energy.2012.12.026

Seta, F. T., An, X., Liu, L., Zhang, H., Yang, J., Zhang, W., et al. (2020). Preparation and characterization of high yield cellulose nanocrystals (CNC) derived from ball mill pretreatment and maleic acid hydrolysis. Carbohydr. Polymers 2020:115942. doi: 10.1016/j.carbpol.2020.115942

Shah, V., Jurjevic, M., and Badia, D. (2007). Utilization of restaurant waste oil as a precursor for sophorolipid production. Biotechnol. Prog. 23, 512-515.

Shekhar, S., Sundaramanickam, A., and Balasubramanian, T. (2015). Biosurfactant producing microbes and their potential applications: a review. Crit. Rev. Env. Sci. Tech. 45, 1522-1554.

Sindhu, R., Binod, P., and Pandey, A. (2016). Biological pretreatment of lignocellulosic biomass - an overview. Bioresour. Technol. 199, 76-82.

Sindhu, R., Silviya, N., Binod, P., and Pandey, A. (2013). Pentose-rich hydrolysate from acid pretreated rice straw as a carbon source for the production of poly-3-hydroxybutyrate. Biochem. Eng. J. 78, 67-72. doi: 10.1016/j.bej.2012.12. 015

Singh, N., Goel, G., Singh, N., Pathak, B. K., and Kaushik, D. (2015). Modeling the red pigment production by Monascus purpureus MTCC 369 by artificial neural network using rice water based medium. Food Biosci. 11, 17-22. doi: 10.1016/j.fbio.2015.04.001

Sobrinho, H. B. S., Rufino, R. D., Luna, J. M., Salgueiro, A. A., Campos- Takaki, G. M., Leite, L. F. C., et al. (2008). Utilization of two agroindustrial by-products for the production of a surfactant by Candida sphaerica UCP0995. Process Biochem. 43, 912-917.

Solaiman, D. K. Y., Ashby, R. D., Nunez, A., and Foglia, T. A. (2004). Production of sophorolipids by Candida bombicola grown on soy molasses as substrate. Biotechnol. Lett. 26, 1241-1245.

Solaiman, D. K. Y., Ashby, R. D., Zerkowski, J. A., and Foglia, T. A. (2007). Simplified soy molasses-based medium for reduced-cost production of sophorolipids by Candida bombicola. Biotechnol. Lett. 29, 1341-1347.

Solarte-Toro, J. C., Romero-García, J. M., Martínez-Patiño, J. C., Ruiz-Ramos, E., Castro-Galiano, E., and Cardona-Alzate, C. A. (2019). Acid pretreatment of lignocellulosic biomass for energy vectors production: a review focused on operational conditions and techno-economic assessment for bioethanol production. Renew. Sust. Energ. Rev. 107, 587-601. doi: 10.1016/j.rser.2019.02. 024

Stahl, W., Nicolai, S., and Briviba, K. (1997). Biological activities of natural and synthetic carotenoids: induction of gap junctional communication and singlet oxygen quenching. Carcinogenesis 18, 89-92. doi: 10.1093/carcin/18.1.89

Sukan, A., Roy, I., and Keshavarz, T. (2014). Agro-Industrial Waste Materials as Substrates for the Production of Poly(3-Hydroxybutyric Acid). J. Biomater. Nanobiotechnol. 5, 229-240. doi: 10.4236/jbnb.2014.54027

Sun, J., Wang, W., Yue, Q., Ma, C., Zhang, J., Zhao, X., et al. (2016). Review on microwave-metal discharges and their applications in energy and industrial processes. Appl. Energy 175, 141-157. doi: 10.1016/j.apenergy.2016.04.091

Szczerbowski, D., Pitarelo, A. P., Zandoná Filho, A., and Ramos, L. P. (2014). Sugarcane biomass for biorefineries: comparative composition of carbohydrate and non-carbohydrate components of bagasse and straw. Carbohydr. Polym. 114, 95-101. doi: 10.1016/j.carbpol.2014.07.052

Tan, J. P., Tee, Z. K., Wan Isahak, W. N. R., Kim, B. H., Asis, A. J., and Md Jahim, J. (2018). Improved fermentability of pretreated glycerol enhanced bioconversion of 1,3-propanediol. Ind. Eng. Chem. Res. 57, 12565-12573. doi: 10.1021/acs.iecr. 8 b02268

Tan, Y. N., and Li, Q. (2018). Microbial production of rhamnolipids using sugars as carbon sources. Microb. Cell Fact. 17:89. doi: 10.1186/s12934-018-0938-3

Terán-Hilares, R., de Souza, R. A., Marcelino, P. F., da Silva, S. S., Dragone, G., Mussatto, S. I., et al. (2018). Sugarcane bagasse hydrolysate as a potential feedstock for red pigment production by Monascus ruber. Food Chem. 245, 786-791. doi: 10.1016/j.foodchem.2017.11.111

Terán-Hilares, R., Dionízio, R. M., Sanchez, S., Prado, C. A., De Sousa-Júnior, R., Da Silva, S. S., et al. (2020). Hydrodynamic cavitation-assisted continuous pre-treatment of sugarcane bagasse for ethanol production: effects of geometric parameters of the cavitation device. Ultrason. Sonochem. 63:2020.

Terán-Hilares, R., Orsi, C. A., Ahmed, M. A., Marcelino, P. F., Menegatti, C. R., da Silva, S. S., et al. (2017). Low-melanin containing pullulan production from sugarcane bagasse hydrolysate by Aureobasidium pullulans in fermentations assisted by light-emitting diode. Bioresour. Technol. 230, 76-81.

Terán-Hilares, R. T., Resende, J., Orsi, C. A., Ahmed, M. A., Lacerda, T. M., da Silva, S. S., et al. (2019). Exopolysaccharide (pullulan) production from sugarcane bagasse hydrolysate aiming to favor the development of biorefineries. Int. J. Biol. Macromol. 127, 169-177. doi: 10.1016/j.ijbiomac.2019.01.038

Thaniyavarn, J., Chianguthai, T., Sangvanich, P., Roongsawang, N., Washio, K., Morikawa, M., et al. (2008). Production of sophorolipid biosurfactant by Pichia anomala. Biosci. Biotech. Biochem. 72, 2061-2068.

Thompson, D. N., Fox, S. L., and Bala, G. A. (2001). Biosurfactants from potato process effluents. Appl. Biochem. Biotechnol. 84, 917-930.

Torres-León, C., Ramírez-Guzman, N., Londoño-Hernandez, L., MartinezMedina, G. A., Díaz-Herrera, R., Navarro-Macias, V., et al. (2018). Food waste and byproducts: an opportunity to minimize malnutrition and hunger in developing countries. Front. Sustain. Food Syst. 2:52. doi: 10.3389/fsufs.2018. 00052

Tsigie, Y. A., Wang, C.-Y., Kasim, N. S., Diem, Q.-D., Huynh, L.-H., Ho, Q.-P., et al. (2012). Oil production from Yarrowia lipolytica Polg using rice bran hydrolysate. J. Biomed. Biotechnol. 2012:378384. doi: 10.1155/2012/378384

Ubando, A. T., Felix, C. B., and Chen, W.-H. (2019). Biorefineries in circular bioeconomy: a comprehensive review. Bioresour. Technol. 299:122585. doi: 10. 1016/j.biortech.2019.122585

Unrean, P., and Ketsub, N. (2018). Integrated lignocellulosic bioprocess for coproduction of ethanol and xylitol from sugarcane bagasse. Ind. Crops Prod. 123, 238-246. doi: 10.1016/j.indcrop.2018.06.071

Urnau, L., Colet, R., Reato, P. T., Burkert, J. F. D. M., Rodrigues, E., Gomes, R., et al. (2019). Use of low-cost agro-industrial substrate to obtain carotenoids from phaffia rhodozyma in a bioreactor. Ind. Biotechnol. 15, 25-34. doi: 10.1089/ind. 2018.0027

Usmani, Z., Sharma, M., Gupta, P., Karpichev, Y., Gathergood, N., Bhat, R., et al. (2020). Ionic liquid based pretreatment of lignocellulosic biomass for enhanced bioconversion. Bioresour. Technol. 304:123003. doi: 10.1016/j.biortech.2020. 123003

Vasconcelos, A. F. D., Dekker, R. F. H., Barbosa, A. M., Carbonero, E. R., Silveira, J. L. M., Glauser, B., et al. (2013). Sulfonation and anticoagulant activity of fungal exocellular $\beta$-(1 $\rightarrow 6$ )-D-glucan (lasiodiplodan). Carbohydr. Polym. 92, 1908-1914.

Veana, F., Martínez-Hernández, J. L., Aguilar, C. N., Rodríguez-Herrera, R., and Michelena, G. (2014). Utilization of molasses and sugar cane bagasse for production of fungal invertase in solid state fermentation using Aspergillus niger GH1. Braz. J. Microbiol. 45, 373-377. doi: 10.1590/s1517-83822014000200002

Velmurugan, P., Hur, H., Balachandar, V., Kamala-kannan, S., Lee, K. J., Lee, S. M., et al. (2011). Monascus pigment production by solid-state fermentation with corn cob substrate. JBIOSC 112, 590-594. doi: 10.1016/j.jbiosc.2011. 08.009

Wang, F.-L., Li, S., Sun, Y.-X., Han, H.-Y., Zhang, B.-X., Hu, B.-Z., et al. (2017). Ionic liquids as efficient pretreatment solvents for lignocellulosic biomass. RSC Adv. 7, 47990. doi: 10.1039/c7ra08110c

Werpy, T., and Petersen, G. (2004). Top Value Added Chemicals From Biomass: Volume I - Results of Screening for Potential Candidates From Sugars and Synthesis Gas. U.S. Data From Department of Energy. Available online at: https: //www.nrel.gov/docs/fy04osti/35523.pdf (accessed July 8, 2020).

Wu, Y.-S., Ngai, S.-C., Goh, B.-H., Chan, K.-G., Lee, L.-H., and Chuah, L.H. (2017). Anticancer activities of surfactin and potential application of nanotechnology assisted surfactin delivery. Front. Pharmacol. 8:761. doi: 10. 3389/fphar.2017.00761

Xiao, Y., Xiao, G., and Varma, A. (2013). A universal procedure for crude glycerol purification from different feedstocks in biodiesel production: experimental and simulation study. Ind. Eng. Chem. Res. 52, 14291-14296. doi: 10.1021/ie402003u 
Xu, Y., Sun, M., Zong, X., Yang, H., and Zhao, H. (2019). Potential yeast growth and fermentation promoting activity of wheat gluten hydrolysates and soy protein hydrolysates during high-gravity fermentation. Ind. Crops Prod. 127, 179-184. doi: 10.1016/j.indcrop.2018.10.077

Yachmenev, V., Condon, B., Klasson, T., and Lambert, A. (2009). Acceleration of the enzymatic hydrolysis of corn stover and sugar cane bagasse celluloses by low intensity uniform ultrasound. J. Biobased Mater. Bioenergy 3, 25-31.

Yañez-Ocampo, G., Somoza-Coutiño, G., and Blanco-González, C. (2017). Utilization of agroindustrial waste for biosurfactant production by native bacteria from chiapas. Open Agric. 2, 341-349.

Yaşar, F. (2020). Comparision of fuel properties of biodiesel fuels produced from different oils to determine the most suitable feedstock type. Fuel 264:116817. doi: 10.1016/j.fuel.2019.116817

Yazan, D. M., Mandras, G., and Garau, G. (2017). Environmental and economic sustainability of integrated production in bio-refineries: the thistle case in Sardinia. Renew. Energy 102, 349-360. doi: 10.1016/j.renene.2016.10.055

Ye, M., Yuan, R.-Y., He, Y.-L., Du, Z.-Z., and Ma, X.-J. (2013). Phosphorylation and anti-tumor activity of exopolysaccharide from Lachnum YM120. Carbohydr. Polym. 97, 690-694. doi: 10.1016/j.carbpol.2013.05.033

Yen, H. W., Chang, J. T., and Chang, J. S. (2015). The growth of oleaginous Rhodotorula glutinis in an internal-loop airlift bioreactor by using mixture substrates of rice straw hydrolysate and crude glycerol. Biomass Bioenerg. 80, 38-43. doi: 10.1016/j.biombioe.2015.04.026

Yu, J., and Stahl, H. (2008). Microbial utilization and biopolyester synthesis of bagasse hydrolysates. Bioresour. Technol. 99, 8042-8048. doi: 10.1016/j. biortech.2008.03.071

Yunus, F., Nadeem, M., and Rashid, F. (2015). Single-cell protein production through microbial conversion of lignocellulosic residue (wheat bran) for animal feed. J. Inst. Brew. 121, 553-557. doi: 10.1002/jib.251

Zhang, B., Zhang, R., Huang, D., Shen, Y., Gao, X., and Shi, W. (2020). Membrane fouling in microfiltration of alkali/surfactant/polymer flooding oilfield wastewater: effect of interactions of key foulants. J. Colloid Interf. Sci. 570, 20-30. doi: $10.1016 /$ j.jcis.2020.02.104
Zhang, K., Yu, C., and Yang, S. T. (2015). Effects of soybean meal hydrolysate as the nitrogen source on seed culture morphology and fumaric acid production by Rhizopus oryzae. Process. Biochem. 50, 173-179. doi: 10.1016/j.procbio.2014. 12.015

Zhang, Y. Q., Fu, E. H., and Liang, J. H. (2008). Effect of ultrasonic waves on the saccharification processes of lignocellulose. Chem. Eng. Technol. 31, 1510-1515.

Zheng, J., and Rehmann, L. (2014). Extrusion pretreatment of lignocellulosic biomass: a review. Int. J. Mol. Sci. 15, 1896718984.

Zheng, S., Yang, M., and Yang, Z. (2005). Biomass production of yeast isolate from salad oil manufacturing wastewater. Bioresour. Technol. 96, 1183-1187. doi: 10.1016/j.biortech.2004. 09.022

Zhou, Z., Yin, Z., and Hu, X. (2014). Corncob hydrolysate, an efficient substrate for Monascus pigment production through submerged fermentation. Biotechnol. Appl. Biochem. 61, 716-723. doi: 10.1002/bab. 1225

Zhu, J., Rezende, C. A., Simister, R., McQueen-Mason, S. J., Macquarrie, D. J., Polikarpov, I., et al. (2016). Efficient sugar production from sugarcane bagasse by microwave assisted acid and alkali pretreatment. Biomass Bioenerg. 93, 269-278.

Conflict of Interest: The authors declare that the research was conducted in the absence of any commercial or financial relationships that could be construed as a potential conflict of interest.

Copyright $\odot 2020$ Philippini, Martiniano, Ingle, Franco Marcelino, Silva, Barbosa, dos Santos and da Silva. This is an open-access article distributed under the terms of the Creative Commons Attribution License (CC BY). The use, distribution or reproduction in other forums is permitted, provided the original author(s) and the copyright owner(s) are credited and that the original publication in this journal is cited, in accordance with accepted academic practice. No use, distribution or reproduction is permitted which does not comply with these terms. 